Historic, Archive Document

Do not assume content reflects current scientific knowledge, policies, or practices. 



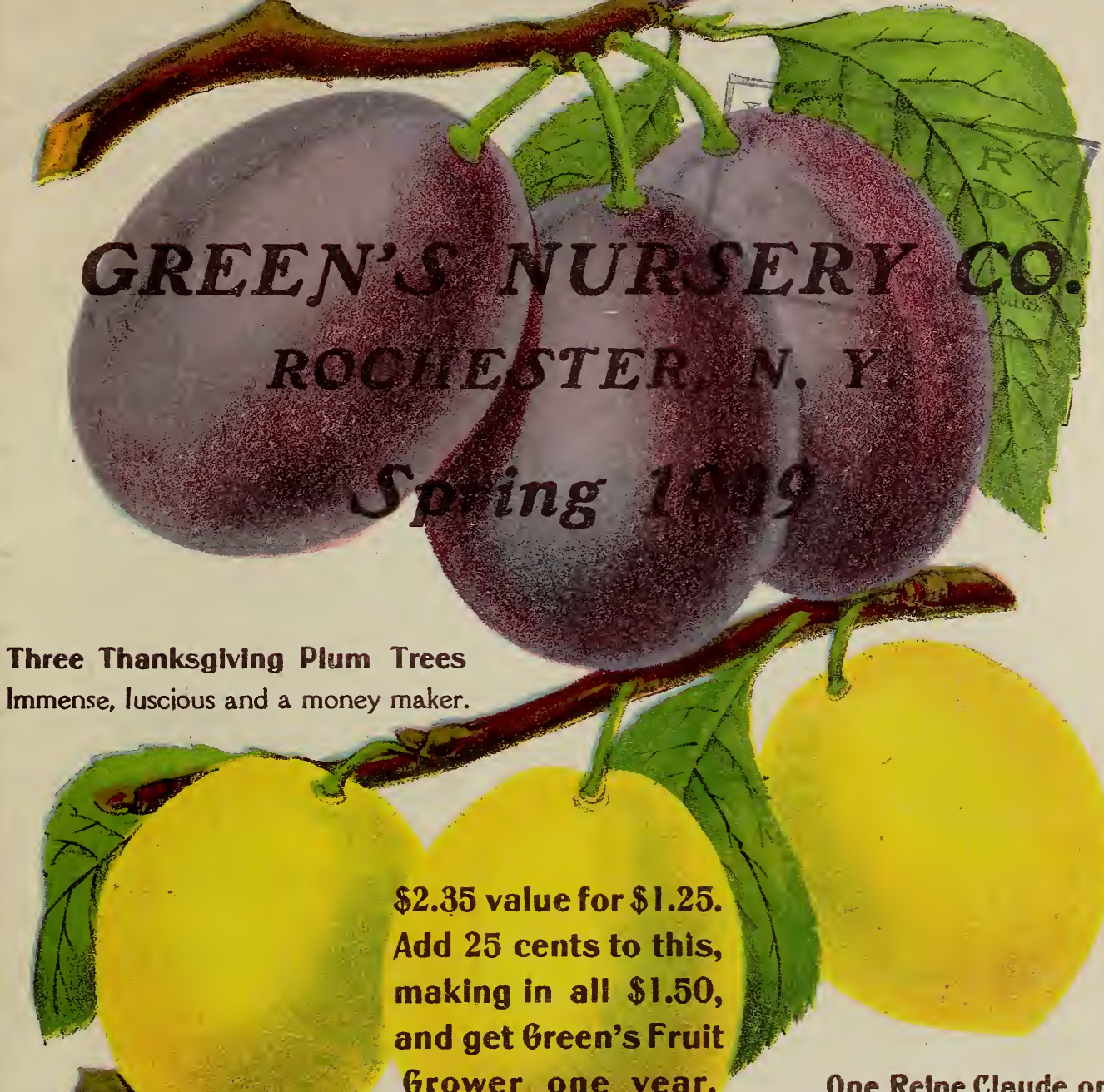

Three Thanksgiving Plum Trees

Immense, luscious and a money maker.

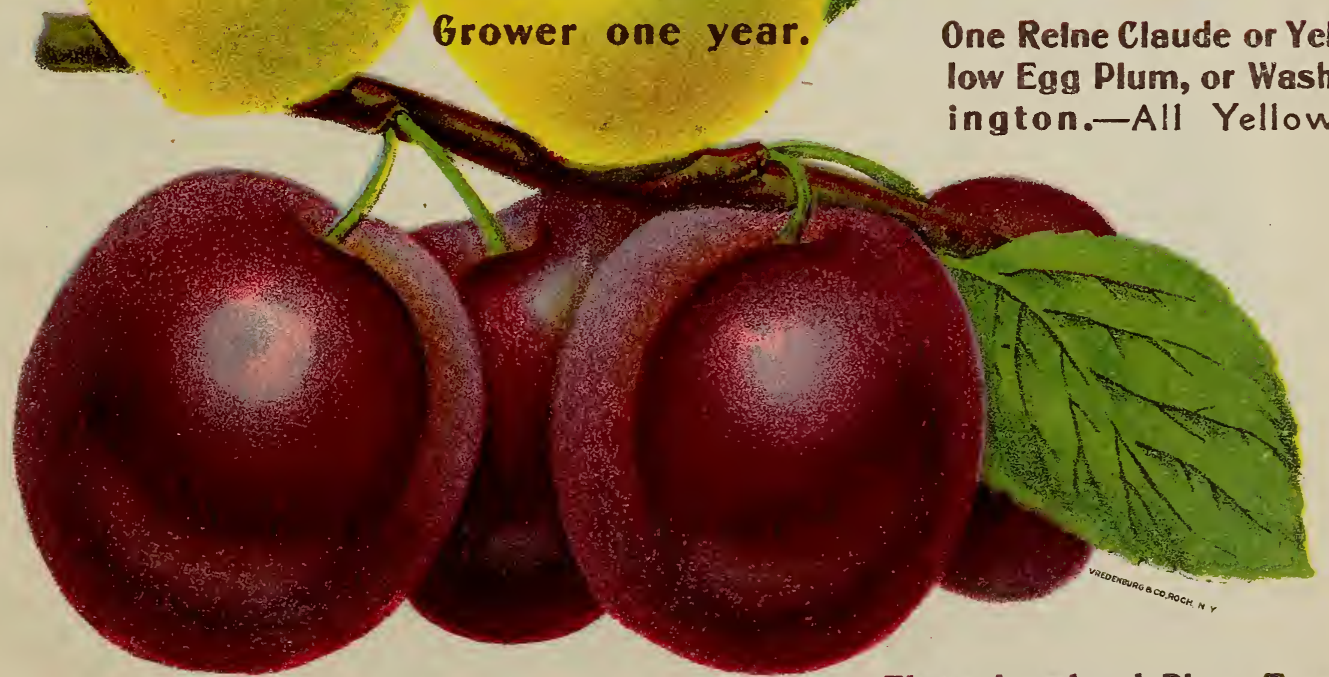

Three Lombąrd Plum Trees

GREEN'S GREAT BARGAIN OFFER-VALUE \$2.35 FOR \$1.25

Three Thanksgiving Plum trees, One Yellow Plum tree as above, three Lombard Plum trees, one Richmond and one Montmorency hardy cherry trees, all the best trees of the largest size, 2 to 3 years old, 6 to $7 \mathrm{ft}$. high, one Elberta Peach tree, and one new and largest Diploma Red Currant, also one Liveforever rose bush, and all offered by GREEN'S NURSERY CO. for \$1.25, carefully packed and put on board cars at Rochester, N. Y.

$$
\text { Value } \$ 2.35 \text { for } \$ 1.25 \text {. GREEN'S NURSERY CO., ROCHESTER, N. Y. }
$$




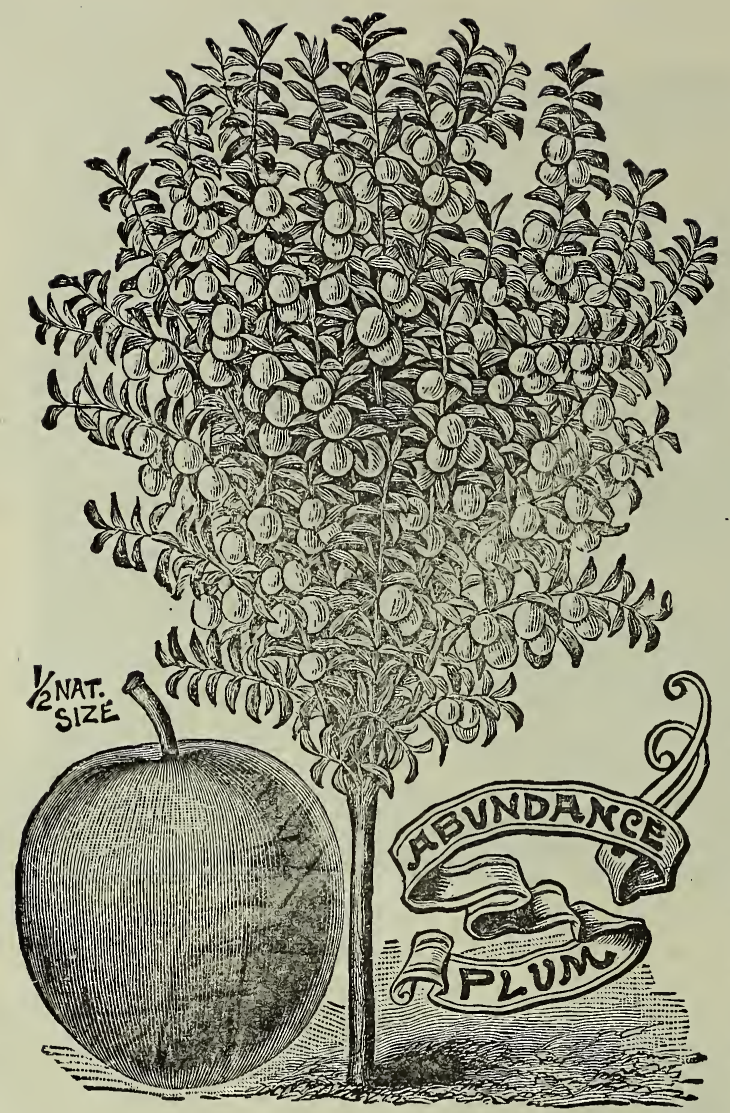

Abundance Japan Plum-

Fruit large, showy and beautiful. Amber, turning to a rich, bright cherry color with a decided white bloom, and highly perfumed. Flesh light yellow, exceedingly juicy and tender and of a delicious sweetness, impossible to describe. Stone small and parts readily from the flesh. For canning it is also of the greatest cxcellence. Its season is very early, ripening in advance of other plums, (in August) adding toits special value.

"The Abundance plum at Green's fruit farm is a sight to behold. The branches are wreaths of fruit, and they, as well as the tree itself, are held up by props and ropes. That the Abundance proves to beall that is claimed for it seems now a settled fact. It is to us a blessing and a revelation-a blessing that we may enjoy plums of our own raising, and a revelation in that we have never been able to raise plums because of the curculio. Here we have an Abundance loaded with beautiful fruit, while not a precaution has been taken to destroy the curculio. Blessed be the Abundance plum. It is well named."

Moore's Arctic-Valuable for its productiveness and extreme hardiness. Fruit grown in clusters. Color dark blue or nearly black when fully ripe. Dr. Hoskins says this is the hardiest plum he has tested, and others make the same report. The heavy demand for the trees of Moore's Arctic indicates its popularity.

Climax Japan Plum-Very large, heart shaped, a superbly rich plum, extremely early, ripens in the coast counties early in July. Color of flesh yellow, sweet and delicious with a pineapple fragrance.

October Purple-Productive; of good quality; a large, round, late purple Japan plum, especially recommended for late market.

Pond's Seedling-A magnificent English plum; form of Yellow Egg; light red changing to violet; flesh rather coarse. Tree a vigorous grower and most abundant bearer.

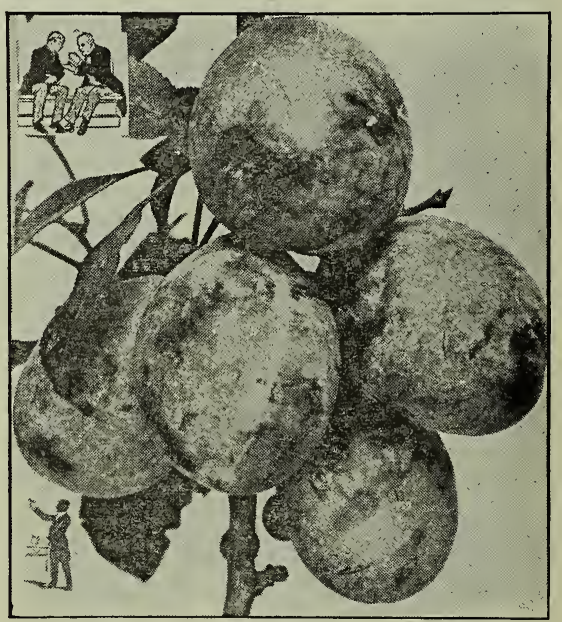

POND'S SEEDLING PLUMS

Price for Plum trees of all varieties on this page : First-class trees, orchard planting size, 4 to 5 feet high, 2 years, $15 \mathrm{c}$. each, $\$ 1.50$ per $12, \$ 10.00$ per 100 . Extra size, 2 years, 20c. each, $\$ 2.00$ per $12, \$ 13.50$ per 100. Small size trees, 3 to 4 feet high, $10 \mathrm{c}$. each, $\$ 1.00$ per $12, \$ 7.00$ per 100 . 


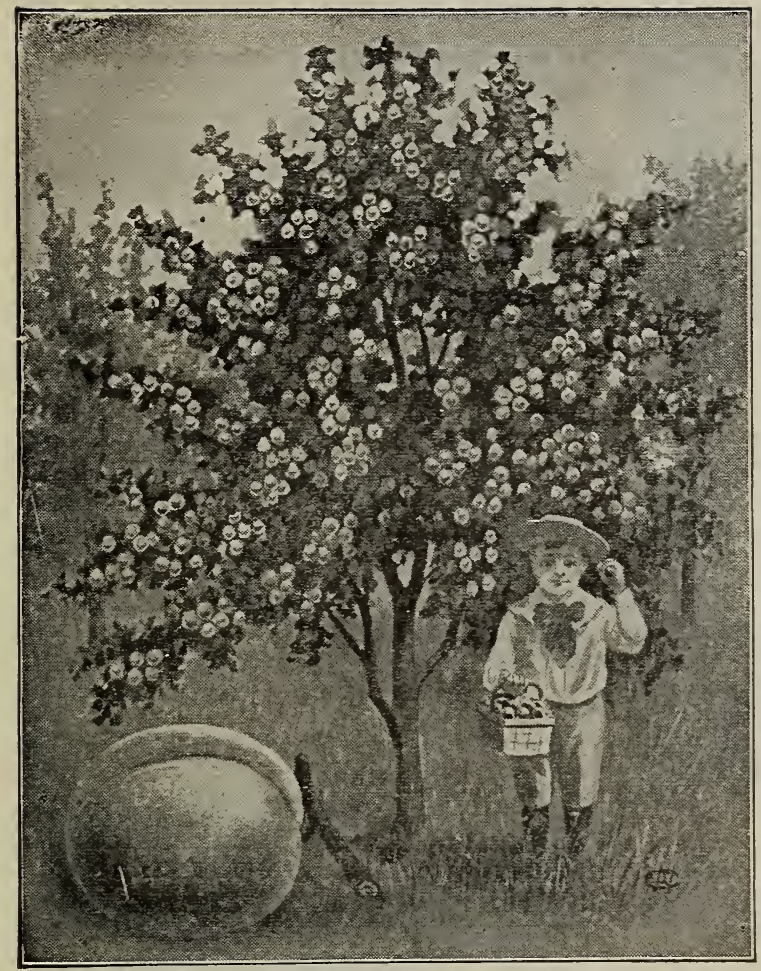

THE WONDERFUL LOMBARD PLUM TREE.

\section{Lombard Plum.}

Extremely Hardy and Productive

The Lombard is a great favor. ite for the following reasons; The tree seems to adapt itself to any locality; it is extremely hardy, producing good crops where many varieties will not grow; it is a strong growing tree-trees on our grounds five years of age being as large again as some varieties planted the same year; it is exceedingly productive. My experience has been that it outyields most other varieties, and yet all varieties of plums are remarkably productive. It is not equal to some varieties in quality, and yet it is enjoyable eaten out of hand and desirable for canning and other domestic purposes. The fruit usually hangs so thick on the limbs that we are compelled to thin out one half. The more you thin it, the larger, brighter and better the remaining fruit will be. It is a handsome reddish plum, the flesh yellow, juicy and pleasant. SeasonAugust. It is an excellent variety, and should be planted in all gardens and orchards. It can be relied upon for a crop often when some other varieties fail.

Price of Lombard Plum Trees: 2 years, largest size, 20c. each, $\$ 2.00$ per $12, \$ 13.50$ per 100 . Miedium size, 2 years, $15 \mathrm{c}$. each, $\$ 1.50$ per $12, \$ 10.00$ per 100 . Smaller size trees, 4 feet high, $10 \mathrm{c}$. each, $\$ 1.00$ per $12, \$ 7.00$ per 100 .

\section{BRADSHAW PLUM.}

A very large and fine early plum, dark violet red, juicy and good. Trees erect and vigorous; very productive; valuable for market. The tree is very hardy and vigorous. As regards productiveness it is unequaled by any plum we have ever fruited. To produce the finest fruit, heavy thinning should be practiced. The quality is excellent, and it is destined to become one of the most popular of all plums for canning, while ts attractive color, good quality and shipping properties will cause it to be sought for as a market variety. It ripens ten days to two weeks later than Abundance. This plum resembles Niagara in size, color and general good qualities. It is a grand variety, and no collection is complete without it. It is becoming better known each year, and it is a great favorite for home use, on account of its fine quality, and for market for the reason that it is possessed of great beauty, large size, and is enormously productive.

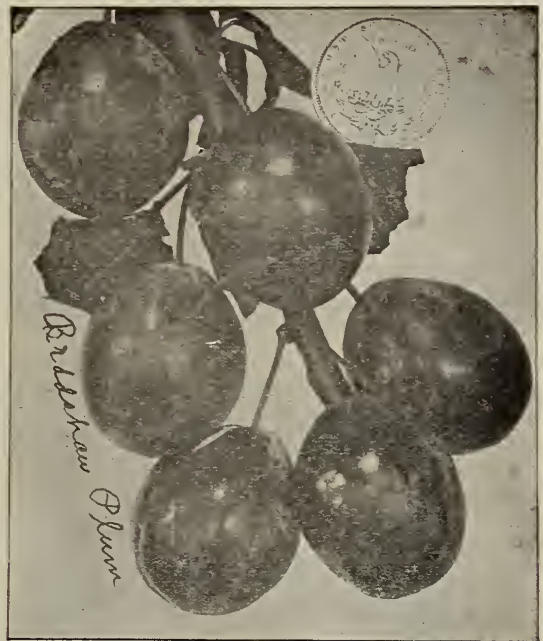

Price for Bradshaw Plum Trees: First-class trees, orchard planting size, 4 to 5 feet highh, 2 years, $15 \mathrm{c}$. each, $\$ 1.50$ per $12, \$ 10$ per 100 . Extra size, 2 years, 20 c. each, $\$ 2.00$ per $12, \$ 13.50$ per 100 . Smaller size trees, 4 feet high, 10c. each, $\$ 1.00$ per $12, \$ 7.00$ per 100 . 


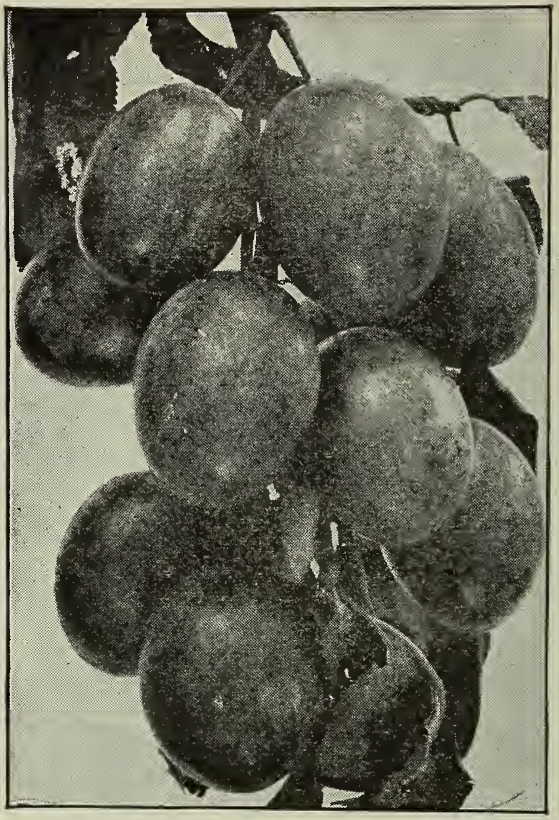

GUEI PLUIMS

Gueii-(Blue Magnum Bonum)-This is one of the newer varieties originating in New York state. Season of ripening rather late. The color is a dark purple. The flesh is firm, sub-acid and agreeable. Size large. It would be difficult to select a larger or more attractive plum for the garden or orchard than this.

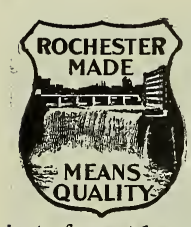

Grand Duke Plum-This magnificent variety ripening the latter part of September. It is of the largest size. In color it is almost red or redish purple. It is one of the best late plums for market, of great value for the home garden. Note that Grand Duke Plum is free from rot. The high grade and great beauty of this plum will make it popular. The tree itself is an object of great beauty. C. A. Green says do not fail to plant the Grand Duke plum.

Beauty of Naples Plum-A dessert plum of highest quality, medium size, greenish yellow, somewhat striped; very sweet, hardy, a good grower.

\section{Green's Biǵ Plum Collection NNo. 999} 20 PLUM TREES FOR $\$ 3.24$
5 Burbank,
3 Lombard,
3 Bradshaw,
2 Red June,
I Beauty of Naples,
2 Shipper's Pride,
2 Thanksgiving,
2 Gueii,

4 Live-Forever Rose Bushes.

A11 largest size trees, 6 to 7 feet hign, f. o. b. here.

20 PLUM TREES, SPECIAL BARGAIN PRICE \$3.24
Shropshire Damson Plum-This is the best of the Damsons. These are smallish plums, produced in thick clusters or groups, almost hiding the branches from view. It is highly prized for canning and for preserving. The tree is not a rapid grower in the nurseries, is difficult to propagate, therefore trees are always in short supply, and cannot be sold as low as other plum trees.

German Prune-Medium; oval; purple or blue; juicy, rich, fine. Tree vigorous and very productive. One of the best. September. Sells for higher prices in market on account of high quality. A leading favorite. There is no easily grown fruit that gives greater or more certain profit than the German Prune. They were introduced in this country by Germans many years ago, and for a time these furnished the only market for them. But the prune as a fruit for drying has entirely surpassed the plum, and though it is always dried whole, the seed is not troublesome to the eater. The Pacific Coast States have furnished most of the prunes for commerce, but it is a fruit that succeeds equally well in the East, with the advantage that if more grown near our large cities, there will be considerable demand for the fruit for eating when ripened, but not dried.

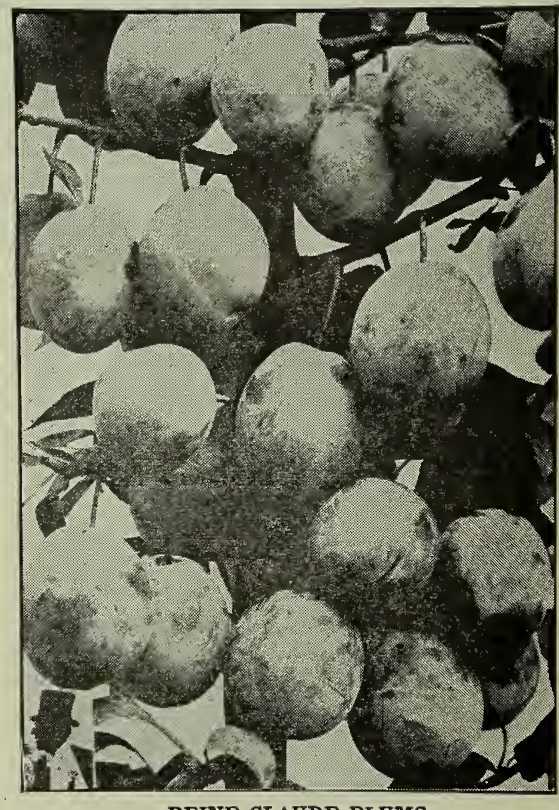

REINE CLAUDE PLUMS

Reine Claude-(Bavay's Green Gage)Roundish, oval, greenish, marked with red in the sun; a great favorite; of fine quality, tree a good grower and remarkably productive. Middle of September.

Price for all varieties of Plums named above : First-class trees, orchard planting size, 4 to 5 feet high, 2 years, $15 \mathrm{c}$. each, $\$ 1.50$ per $12, \$ 10.00$ per 100 . Extra size trees, 2 years, 20c. each, $\$ 2.00$ per $12, \$ 13.50$ Per 100. Smaller size trees, 4 feet high, 10c. each, $\$ 1.00$ per $12, \$ 7.00$ per 100. 


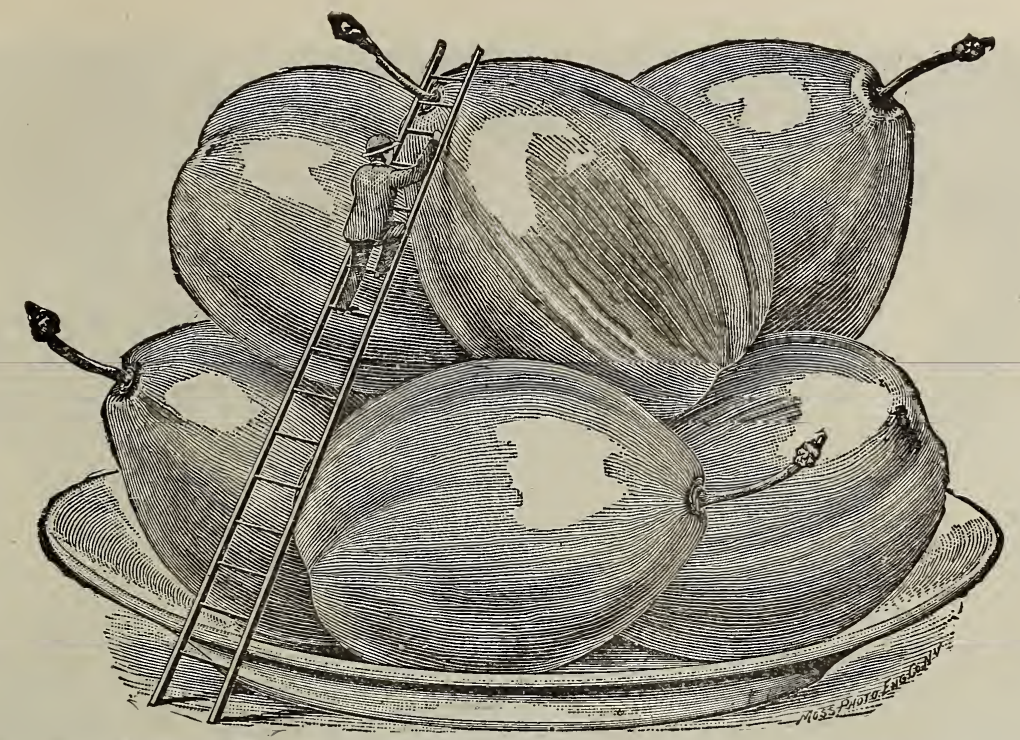

YORK STATE PRUNE, LARGE, BEAUTIFUL AND OF SUPERIOR QUALITY.

York State is one of the largest, best in quality and most productive of all prunes or plums. Size large ; color dark blue, covered with purple blush ; flesh yellow and delicious ; freestone, ripening the last week in August, at Rochester, N. Y. This prune is originated at Dansville, N. Y., where it has been grown largely by the Germans, who are great fruit growers. It is a seeding of the German Prune and has been sold by the Germans for German Prune to Buffalo fruit buyers in large quantities at profitable prices. It resembles Fellemberg more than it does German Prune. York State Prune is a vigorous grower, and is healthy and hardy here at Rochester.

Price of York State Prune; First-class trees, 5 feet high, 20c. each, $\$ 2.00$ per $12, \$ 13.00$ per 100 Extra size, 6 feet high, 25c. each, $\$ 2.50$ per $12, \$ 16.00$ per 100 . Small size trees, 3 to 4 feet high, 15c each, $\$ 1.50$ per $12, \$ 10.00$ per 100 .

Wickson Japan Plum is another of Burbank's creations, and the largest of all plums. Tree a good grower of vase-like form, and an early and productive bearer.

Satsuma Japan Plum-The fruit is rather large, sometimes two inches in diameter or more; color dark purplish-black; skin almost tough; flesh firm, juicy, dark purple, flavor rather tart, peculiar; quality best.

\section{RED JUNE,}

\section{a Valuable Early Market Plum}

Red June Japan Plum-A vigorous, hardy, upright, spreading tree, as productive as Abundance ; fruit medium to large, deep vermilion-red, with handsome bloom, very showy; flesh light lemon-yellow, slightly sub-acid, of good and pleasant quality; half cling; pit small. Of immense value for its very early ripening. It is best in quality of any of the early Japanese varieties and is exceptionally free from rot. Tree strong and spreading, immensely productive and comes into bearing in two or three years.

Price for all varieties of Japan Plums named above: First-class trees, orchard planting size, 4 to 5 feet high, 2 years, 15c. each, $\$ 1.50$ per $12, \$ 10.00$ per 100 . Extra size, 2 years, 20c. each, $\$ 2.00$ per 12 , $\$ 13.50$ per 100. Small size trees, 3 to 4 feet high, 10c. each, $\$ 1.00$ per 12, $\$ 7.00$ per 100 .

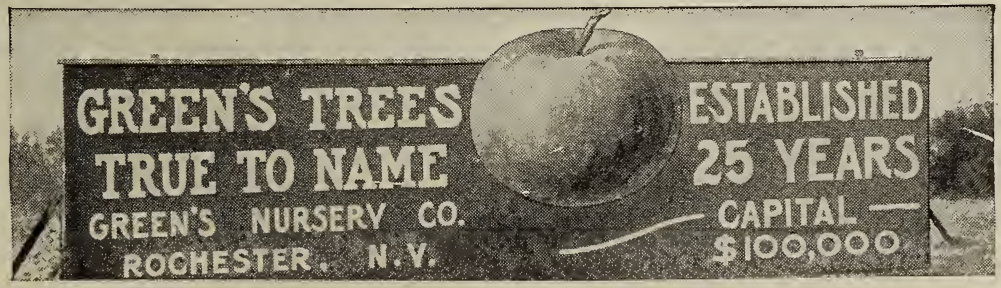




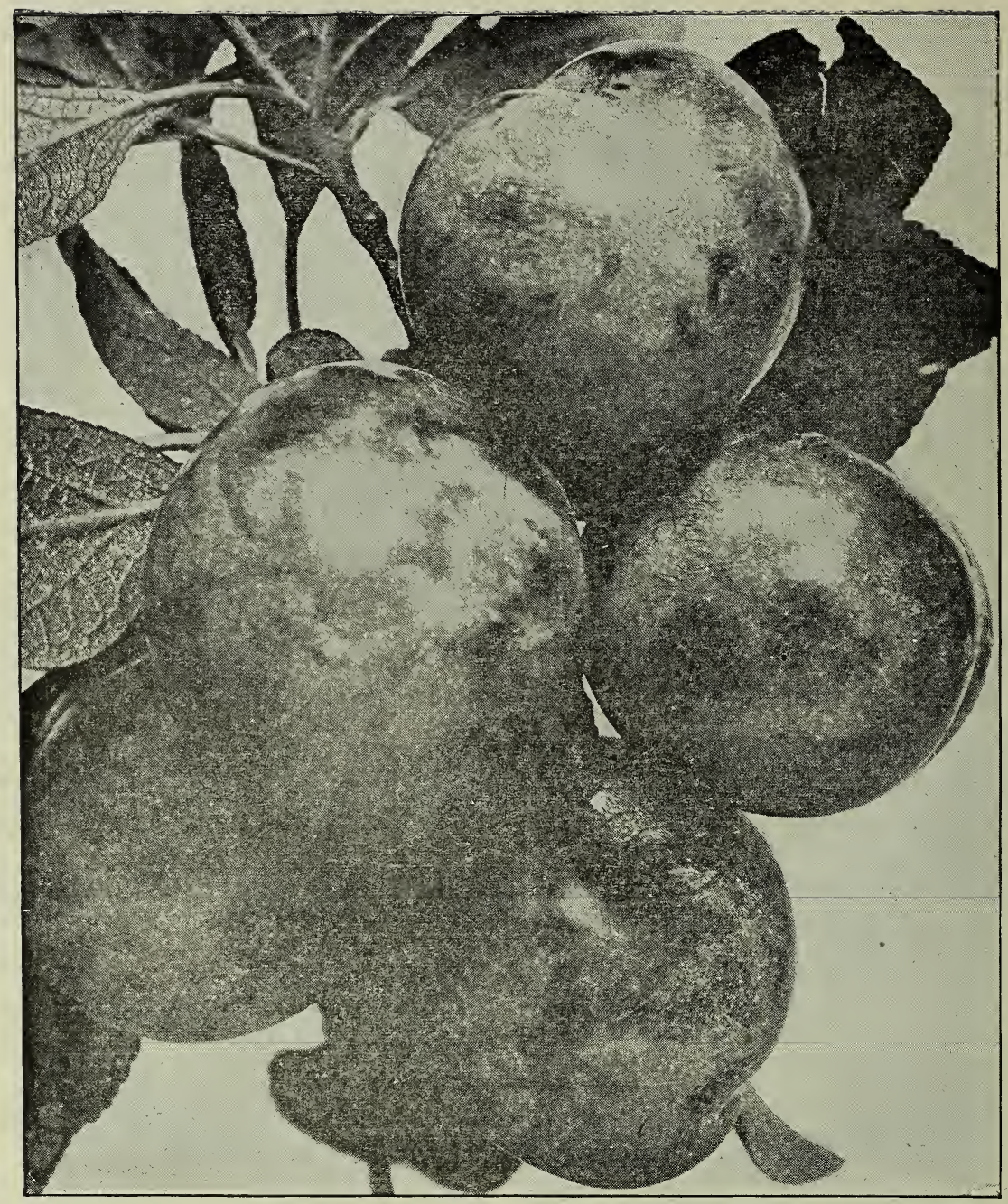

\section{THANKSGIVING PLUIM, VERY HARDY and PRODUCTIVE}

\section{RIPENS OCTOBER FIRST.}

The Thanksgiving Hardy Plum-Very Productive, good quality and long keeper. It will keep for weeks and months after picking like an apple. Another year's experience with this valuable plum leads us to think that we have not claimed enough for it. We did not know that it was a very hardy variety until the winter of Igo4 established that fact. This winter was the most severe ever experienced, and in consequence nearly all plum trees growing in the nursery rows in this country were injured or destroyed. The Thanksgiving Plum stood up nobly, not being hurt in the least, where all other varieties but natives were destroyed. Notice that Thanksgiving Plum is not only a variety of superior merit in many other respects, but that it is hardy makes this one of the most valuable varieties of the age. Thanksgiving Plum is also a very vigorous grower; it makes a nice straight tree in the nursery row.

Price of Thanksgiving Plum Trees : 2 years, largest size, 25c. each, $\$ 2.50$ per $12, \$ 16.00$ per 100 . Medium size, 2 years, 20 c. each, $\$ 2.00$ per $12, \$ 13.00$ per 100 . Small size, 15c. each, $\$ 1.50$ per $12, \$ 10.00$ per 100. 


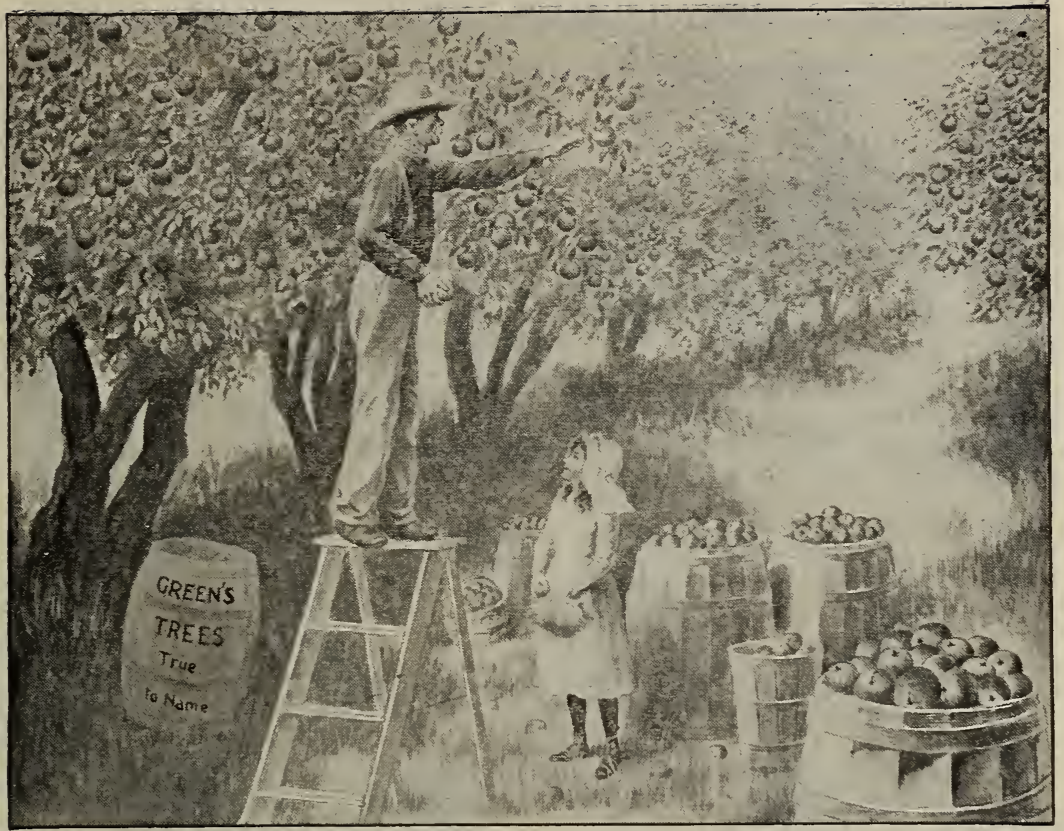

NORTHERN SPY APPLE.

\section{Complete list and prices for the different Standard varieties of Apple} Trees Grown and for sale by us:

AMERICAN BLUSH
*Alexander
BALDWIN
*BANANA
BEN DAVIS
Bellflower
*BISMARK
BLENHEIM PIPPIN
DUCHESS OF 0.
Early Harvest
Fall Pippin
Fanny
Fameuse
Gen. Grant
Gano
Garden Royal

*Gloria Mundi
Gravenstein
Grimes Golden
*GREENS BALDWIN
Golden Russet
Early Strawberry
Golden Sweet
HUBBARDSTON
Hyslop Crab
Jacob Sweet
Jonathan
King
LORD NELSON
MAIDEN'S BLUSH
McINTOSH
Mann

M. B. Twig

Minkler

Missing Link

Martha Crab

North Star

N SPY

N. W. Greening

Ontario

Penna. Red

Pewaukee

Pound Sweet

Princess Louise

RAMBO

RED ASTRACHAN

Red Siberian Crab

*R. I. Greening

\author{
ROME BEAUTY \\ Roxbury Russet \\ SCHIAWASSE BEAUTY \\ Stark \\ SUTTON BEAUTY \\ Sweet Bough \\ Tolman's Sweet \\ TRANSCENDANT CRAB \\ Scott's Winter \\ WAGENER \\ WEALTHY \\ Winesap \\ WISMER'S DESSERT \\ Wolf River \\ *YELLOW TRANSPARENT \\ YORK IMPERIAL
}

The varieties in heavy black type are our main varieties, our leaders. The varieties with $*$ star attached are a little higher in price than the general list. See descriptions. The varieties in common type whether described or not are in small supply and the prices, 25c, 20c, and $\mathrm{I}_{5} \mathrm{c}$ each according to size.

Prices of varieties with * star attached are Largest size 30c. each, Medium size 25c. each, smaller size, 20c. each. Price of other varieties of Apple trees, as above, 25 cents each, for largest; 2U cenis eacn for medium size, and 15 cents each for small size, which are 2 to 3 years old, 4 to 6 feet high.

APPLE TREES are in very short supply everywhere. Orders should be sent early and second choice named, or order marked no substitution on variety, if no other variety acceptable.

American Sweet Chestnut, 4 to 5 feet high, 50 cents each, $\$ 5$ per 12,3 to 4 feet 30 c. each, $\$ 3.00$ per 12. See nuts, page 42.

\section{A GOOD REPUTATION}

This is what Charles A. Green has been working for the past twenty-eight years. When he started this business he found dificulty in selli"n his trees but as soon as people found that his trees were TRUE, TO NAME he could hardly grow enough to supply his demand We are compelled each year to increase our capacity, our force of 1 - borers and packers to keep pace with our increasing business. "We have heard from our friends that you are reliable a d a firm dealing fair and we want your trees" write many people. "We want your trees, plants and vines because they prove TRUE TO NAME when fruiting." 


\section{CHERRY TREES FOR MARKET AND GARDEN.}

There are few trees more attractive than the Cherry, on account of its beautiful foliage, its attractive blossoms, and showy fruit. It is more often planted upon the lawn of the village and city, as well as the farm lawn, than other fruit trees. It furnishes a delightful shade and is a clean tree. The cherry tree does better without cultivation than almost any other fruit trees, but if possible the first few years it should be cultivated, or mulched on the surface of the soil with manure. I have heard of a cherry tree that was $61 / 2$ feet in circumference, with a spread of branches measuring 60 feet. Since it bore its first crop it has borne annually without one omission 600 to Iooo pounds, of superior cherries, selling for 7 cents per pound. We seldom hear of a cherry orchard. This may be a good reason why it is profitable to plant cherries. Surely it requires more labor to pick cherries than apples, but the profit is comparatively large. It is usual for people to avoid crops which require much labor, whereas those are the very crops wherein usually the most money can be made. Complaint is often made of birds feeding upon the cherries, but surely they are so productive a few would not be missed, and where the orchard is large the birds make but little impression upon the enormous yield, picking out mainly wormy specimens. The cherry tree bears almost every year, and is an early fruiter.

\section{MORELLO OR HARDY CHERRIES}

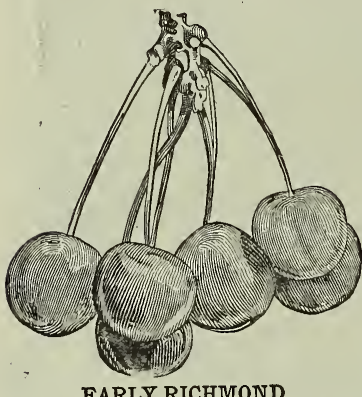

EARLY RICHIMOND
Early Richmond Cherry - An early red, magnificent cherry, veryvaluable for cooking early in the season. Ripens through June. Tree a free grower; hardy, healthy and very productive. One of the best. "If I could plant but one cherry it would be Early Richmond."

It is a safe, reliable, worthy favorite. I have at our fruit farm two rows and a half of Early Richmond cherry trees, each row containing about forty trees.

Late Duke-Large; light red; late and excellent. End of July.

Ostheim-(Russian) Very hardy; skin dark red, flesh reddish, tender, juicy, valuable where extra hardy varieties are required. June

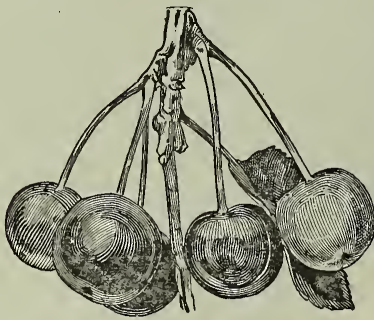

MONTIORENCY, reduced size

Montmorency Cherry - Larg e; bright, shining red; acid; late; valuable. Hardy and productive. $T \mathrm{~h}$ is varietyseems to be almost as popular as the Early Richmond. We seldom have trees enough to supply the demand. Canning houses like this variety. You cannot make a mistake in planting it. "For home use and market the Montmorency is valuable." It is a safe, reliable, worthy favorite. Last of June.

May Duke-An old, well known variety, large; dark red; juicy and rich. Tree hardy and productive; ripens a long time in succession. Middle of June.

Prices and sizes for hardy cherry trees of all varieties on this page : First-class orchard planting trees, 5 feet hióh, 20c. each, $\$ 2.00$ per $12, \$ 16.00$ per 100 . Price for selected largest sized trees, 25c. each, $\$ 2.50$ per 12, \$20.00 per 100. Smaller size, 4 feet highh, 15c. each, $\$ 1.50$ per $12, \$ 12.00$ per 100 .

CERTIFICATE This is to certify that the stock in the nursery of Green's Nursery Co., of Rochester, County of Monroe, State of New York, was duly exmined in compliance with the provisions of Section 83, of the Agricultural Law, and it was found to be apparently free from any contagious or infectious disease or diseases, or San Jose scale or other dangerously injurious insect pest or pests. This certificate expires Sept. I. Dept. of Agriculture, Albany, N. Y.

C. A. WIE'TING, Commissioner of Agriculture.

We certify that the whole and every part of said stock has been examined according to the laws of the State of New York, and found free from San Jose scale or other destructively injurious insects, pests or fungus diseases.

GREEN'S NURSERY CO. 


\section{MORELLO OR HARDY CHERRIES}

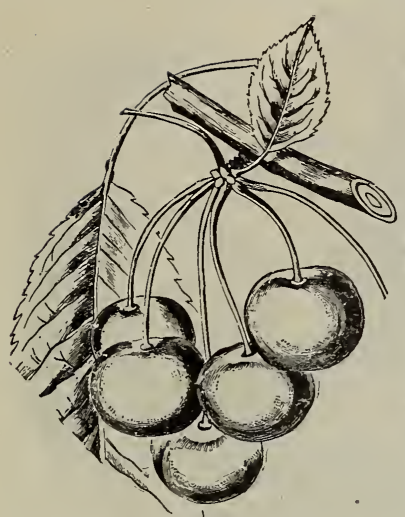

recommended for extremely cold latitudes. August.

Large En-

glish Morello

Cherry-

Wit hout

doubt one of

the most val-

uable of this

class. Easily

grown, generally producing a heavy crop. Fruit dark red, quality good, with a rich, acid flavor; 1ate. Tree very hardy, and
Prices and sizes for hardy cherry trees : Dyehouse and English Morello, First-class orchard planting trees, 5 feet high, $20 \mathrm{c}$. each, $\$ 2.00$ per $12, \$ 16.00$ per 100 . Price for selected largest sized trees, $25 \mathrm{c}$. each, $\$ 2.50$ per $12,20.00$ per 100 . Smaller size, 4 feet high, 15 c. each, $\$ 1.50$ per $12, \$ 12.00$ per 100 .

\section{SWEET VARIETIES OF CHERRIES}

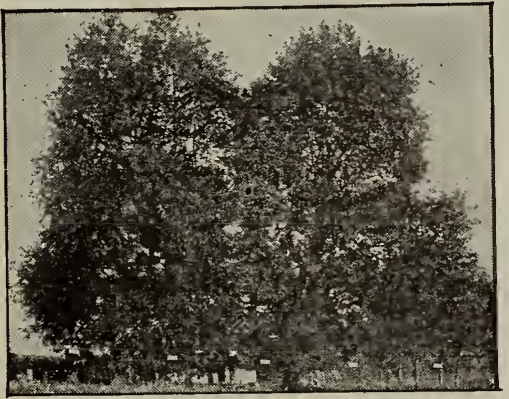

A LARGE SWEET CHERRY TREE.

Windsor Cherry-Tree upright, vigorous and rapid grower; leaves large. Fruit large, roundish oblong, very firm, juicy, mottled red; flesh pinkish, sometimes streaked. Quality good, heavy bearer. It hangs a long time and does not rot badly. No cherry of recent years has attracted more attention, owing to its large size, beautiful dark color, almost black; its firmness; its qualifications as a shipper, and its excellent eating qualities. The variety has been recommended by Willard and others of the most prominent fruit growers of the country who have given it a thorough trial, and have found it unexcelled by any variety for home use and for market. It originated in the cold, severe climate of Canada. While we cannot recommend it as being hardy enough for the Northwest, it is a great success in Western New York and the Middle States.
Yellow Spanish-Very large, often an inch in diameter; pale yellow, with a handsome light red cheek next to the sun; flesh firm, with a fine, rich flavor; a general favorite. June.

Governor Wood-One of the best cherries; very large; light yellow, marbled with red; juicy, rich and delicious; tree healthy and a great bearer; hangs well on the tree vigorous. Last of June.

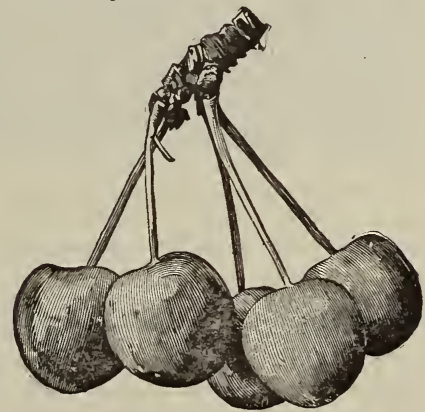

Napoleon Cherry-Tree medium size, erect with roundish head, fruit borne generally in twos; very large oblong cordate; light lemon yellow with red cheek in the sun. Flesh very hard, brittle, colorless, reddish at the stone. Stem of medium length, stout in a moderately deep, even cavity. Good, excellent bearer. Ripe about June 2oth. The Napoleon Bigarreau is probably the most desirable light colored cherry for market purposes.

Price of Sweet Chierry Trees : Napoleon, Windsor, Spanish Yellow and Governor Wood, first-class selected two-year-old trees, 6 to 7 feet high, 35c. each, $\$ 3.50$ per 12. First-class orchard planting size, 5 to 6 feet high, 25c. each, $\$ 2.50$ per 12 . Smaller grade 4 to 5 feet, 20c. each, $\$ 2.00$ per 12. 


\section{SWEET VARIETIES OF CHERRIES}

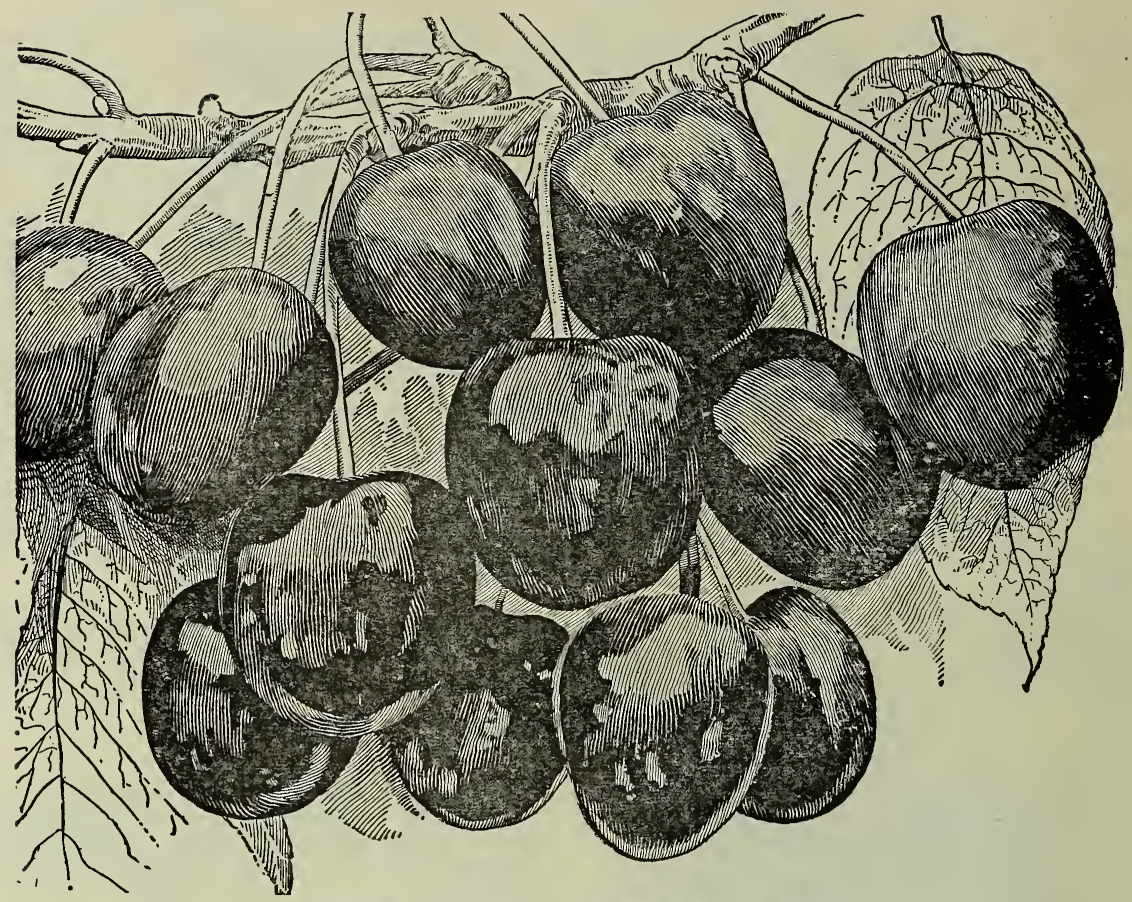

\section{GREEN'S BLACK TARTARIAN CHERRY}

Green's Tartarian Cherry - In front of our Rochester house are two black cherry trees which are something of a wonder to all who see them. These trees never fail to bear a heavy crop of fine fruit. The trees are perhaps forty years old. They have reached an age when most cherry trees begin to fail and to become unproductive, but these trees are as productive as in their earlier years. A notable peculiarity of the fruit upon these trees is that it remains on the trees in an eatable condition for nearly three weeks. I have never known cherries to remain so long upon the trees. The fruit from these trees sells in the market more readily than any other fruit we are acquainted with. It is accepted by our marketmen as the Black Tartarian. It has much the same appearance as the Black Tartarian, and yet we have never known that good old variety to remain so long in perfect condition upon the trees, which is a desirable feature in prolonging the season for family use. We call it Green's Tartarian cherry, not to indicate that it is a new variety, but to indicate that it is what we represent it to be - a superior strain of the Black Tartarian. - First of July.

Price of Sweet Cherry Trees, Green's Tartarian : First-class selected two-year-old trees, 6 to 7 feet high, 35c. each, $\$ 3.50$ per 12 . First-class orchard planting size, 5 to 6 feet high, 30c. each, \$3.00 per 12.

Prof. H. E. VanDeman says as regards Bing and Lambert cherries: "They will be entirely successful anywhere that sweet cherries succeed. Their fruit will be larger and more solid than most cherries of their class. I recommend my friends to plant these varieties." In some eastern town these cherries are so large as to be mistaken for plums.

C. A. GREEN.

Lambert Cherry - (new), one of the largest of all the sweet cherries. So far productive. Color, dark red; flesh, solid; an excellent shipper. Its season being late makes it especially desirable.

Price of Lambert : Large size trees, 75c. each; Medium size, 50c. each.
Bing Cherry. - So large in size as to be mistaken for plums. This new and superior sweet cherry originated near Portland, Oregon, is one of very large size, almost black in color when ripe, of fine quality, very productive, a good shipper.

Price of Bing Cherry Trees, large size, 50c. each ; Medium size, 40c. each.

Cherries Profitable. - Mr. Corser, of whom we bought our Rochester house, says he sold $\$ 66$ worth of cherries from 4 Green's Black Tartarian Cherry Trees. This was an unusal crop of course. It is claimed that as much as $\$ 300$ has been made from one acre of cherries. 


\section{PEACH CULTURE}

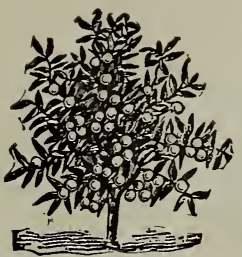

Much has been learned about peach culture within the past four years. At times peach culture has been entirely given up in Western New York and in Connecticut and many other states where now the peach is the most profitable of all orchard crops. It is perhaps the most beautiful, most tempting and luscious of a1l northern fruits. There is no fruit marketed which brings a higher price than well grown peaches. At one time it was supposed that only sandy soil was adapted to peach culture; later, it has been claimed that clayey loam is superior to sandy soil. Peaches will succeed on either sandy or clayey loam, if properly cultivated. Peaches will not thrive in uncultivated soil. The soil should not be made too rich, as the peach is a very rapidly growing tree. It has been recently discovered that there are varieties of peach that are very hardy in bud which scarcely ever fail to bear profitable crops, where other varieties around them are entirely destroyed by the severity of the winter. The number of varieties of peach has been largely increased of late years, somewhat to the bewilderment of the planter. We have aimed to confine our list to the cream, naming only those varieties which we have deemed best, all things considered. A neighbor, from six and five years old peach trees, picked seventy-five baskets of No. I peaches, and five baskets of a lower grade; he sold the best at $\$ 1.00$ per basket and the poor ones for 65 cents per basket, netting $\$ 78.25$.

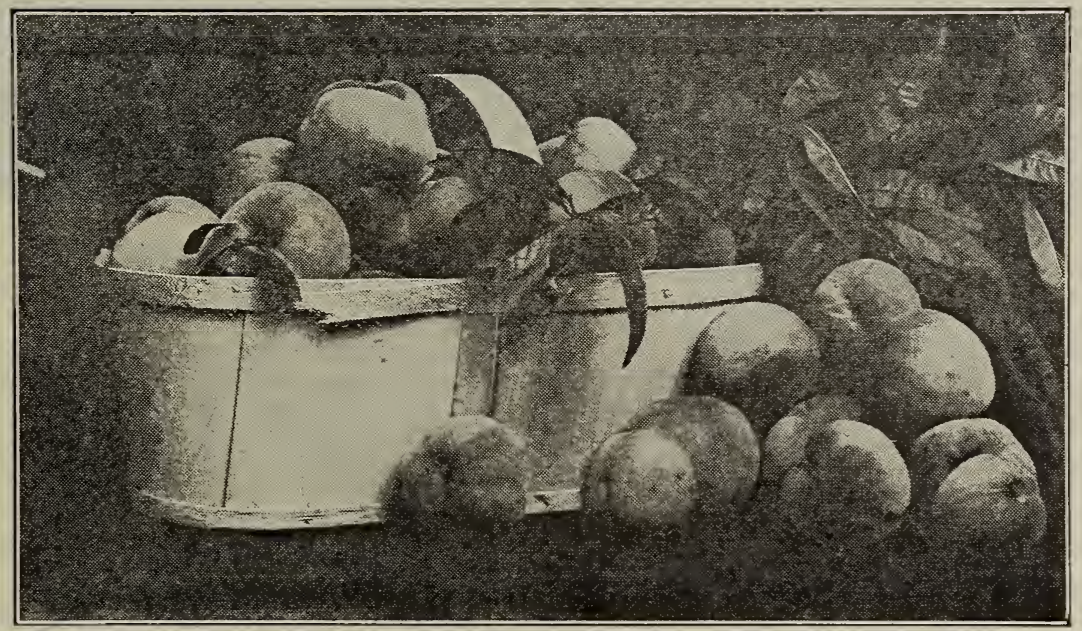

\section{CHAMPION ONE OF THE MOST HARDY PEACHES}

Crosby Frost-proof Peach-A fine, handsome, yellow peach, with remarkably small pit, that bears regular crops north of the peach belt. Quality delicious; season follows quickly after Early Crawford. Crosby is now so well known that it will be no experiment planting it. It has been planted in nearly all peach-growing states, and is spoken of in the highest terms. Many large orchards of this variety have been planted the past season. The strongest claim for its superiority made over other varieties is the frost-proof character of its fruit buds.

Price of Crosby Peach: First-class orchard planting trees, 3 to 4 feet high, well branched, 15c. each, $\$ 1.25$ per $12, \$ 9.00$ per 100 . Price for selected size trees, 18c. each, $\$ 1.75$ per $12, \$ 12.00$ per 100 . Small size trees, 2 to 3 feet high, 10c. each, $\$ 1.00$ per 12, \$6.00 per 100.

\section{GREEN'S PEACH COLLECTION}

12 PEACH TREES FOR $\$ 1.75$

\section{Niagara, $\quad 3$ Early Crawford, \\ 3 Elberta, \\ I Champion, \\ I Crawford Late, I Hill's Chili.}

All trees offered in the above collection are strictly first-class, largest size.

12 PEACH TREES SPECIAL BARGAIN PRICE \$1.75

\section{Green's Biǵ Plum Collection No. 999}

20 PLIJM TREES FOR \$3.24

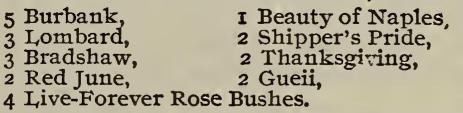

4 Live-Forever Rose Bushes.

All largest size trees, 6 to 7 feet Ligh, packed f. o. b. here.

20 PLUM TREES, SPECIAL BARGAIN PRICE \$3.24 


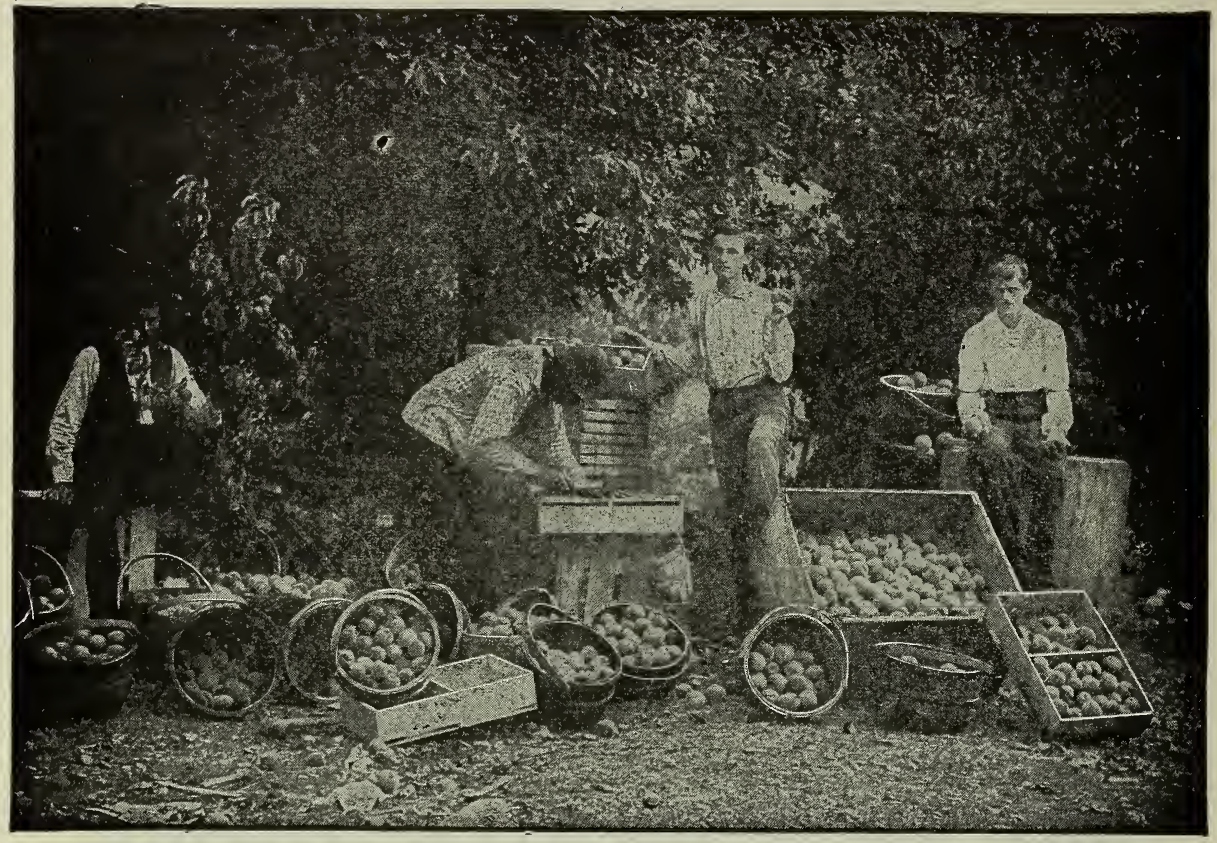

\section{PACKING EARLY CRAWFORD PEACHES FOR MARKET.}

Crawford's Early-A magnificent large yellow peach of good quality. Tree vigorous and prolific ; its size, beauty, and productiveness make it one of the most popular varieties. Season beginning of September. This valuable peach has 1ong been a favorite for large size, beauty, and quality of fruit. IMost people when they buy peaches ask for Crawfords, knowing but little about any other variety. In past years this was the earliest peach, but now much earlier kinds are known, hence it is about mid-season in ripening. Everybody who plants peach trees plants Crawford's Early. A superior variety that should not be omitted.

Price of Early Crawford Peach : First-class orchard planting trees, 3 to 4 feet high, well branched, $15 \mathrm{c}$. each, $\$ 1.25$ per 12, $\$ 9.00$ per 100 . Price for selected size trees: $18 \mathrm{c}$. each, $\$ 1.75$ per $12, \$ 12.00$ per 100 . Small size trees, 2 to 3 feet highh, 10c. each, $\$ 1.00$ per $12, \$ 6.00$ per 100 .

Crawford's Late-A superb yellow peach, very large, productive, and good; ripens here

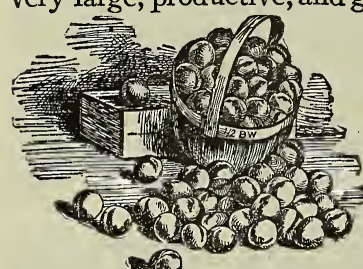

fruit farm. It does not overbear, thus does not need thinning. Its quality is superb.

Champion-Fruit, large, sweet, rich and juicy; skin creamy white, with red cheek, freestone and a good shipper. Ripens early.
Fitzgerald-Grows similar to Crawford and ripens between Early and Late Crawford; flesh rich, deep golden yellow, with high character; certainly a very fine peach. The tree commences bearing young, is productive, and in Canada and Michigan has proven one of the hardiest.

Gold Drop-Large, good quality, hardy; a profitable market sort; follows Crawford Late.

Hill's Chili-Fruit medium size, oblong; skin yellow, shaded with dark red; flesh yellow, very rich and sweet; freestone.

Chair's Choice-Fruit of very large size, yellow, with a red cheek; flesh yellow, firm and of good quality; tree a strong grower and a good bearer. Ripens just before Smock.

Price for all varieties of Peach trees named on this page : First-class orchard planting trees, 3 to 4 feet high, well branched, $15 \mathrm{c}$. each, $\$ 1.25$ per $12, \$ 9.00$ per 100 . Price for selected largest sized trees, $18 \mathrm{c}$. each, $\$ 1.75$ per $12, \$ 12.00$ per 100 . Small size trees, 2 to 3 feet high, $10 \mathrm{c}$, each, $\$ 1.00$ per $12, \$ 6.00$ per 100 , 


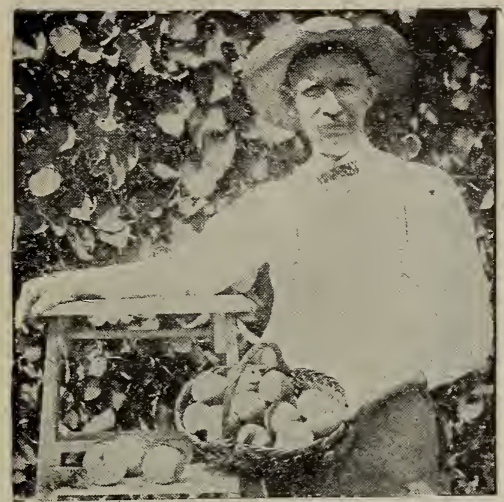

\section{ELBERTA PEACH}

Large and Productive

Elberta Peach-Unsurpassed as a valuable, large, beautiful peach of good quality. The best orchard variety, and valuable also for planting in the garden. A friend near Rochester has planted fifteen acres entirely to Elberta. Elberta is hardier in bud than many varieties, therefore a more uniform cropper. At Green's fruit farm this year we are harvesting a large crop of Elbertas, and yet we had three consecutive frosts last spring that destroyed nearly all peach buds in this 1 o ca 1 ity. M an y people have feared that too many Elbertas would be planted, but I think these fears are groundless, since it is such a valuable variety. Owing to the great demand for The best authority on peaches in the United States, planted 60,000 Elberta. Why? Because he well knew its value. This most excellent variety will be called for by the thousand. Orders should be sent in early, while our stock is large.

Elberta trees, we are compelled to limit somewhat the number of Elberta trees desired with each order, and yet have a large supply of this variety. Elberta is large, yellow, with red cheek, juicy and high flavored, flesh yellow; freestone. Season medium early, following quick upon Early Crawford.

Price of Elberta Peach : First-class orchard planting trees, 3 to 4 feet high, well branched, 15c. each, $\$ 1.25$ per $12, \$ 9.00$ per 100 . Price for selected size trees, $18 \mathrm{c}$. each, $\$ 1.80$ per $12, \$ 12.00$ per 100 . Small size trees, 2 to 3 feet high, 10c. each, $\$ 1.00$ per 12, $\$ 6.00$ per 100 .

\section{NIAGARA PEACHES}

Niagara Peaches-A new variety but fully tested by extensive orchard planting near Rochester, N. Y. It may be called the New Elberta, since in appearance it is just like Elberta. It seems to have all the desirable qualities of Elberta with none of its defects. One defect of Elberta is that the foliage is liable to be affected with the fungus that causes leaf curl, while the foliage of Niagara peach cannot be surpassed in healthfulness and vigor, and for its ability to resist fungus, being almost of the character of leather. Another reason is that while Ellherta is of good fair quality, Niagara is superb in quality and far superior to Elberta. Niagara ripens one week earlier than Elberta, ripening here September Ist. It is remarkably free from yellows and leaf curl. Prof. Van Deman says: "I have heard the Niagara peach spoken of in the highest terms. Those who have fruited it prefer it to any other, and think it even better than Elberta or Early Crawford. I have seen and eaten Niagaıa: It is of large size, beautiful, and better in quality than Elberta.

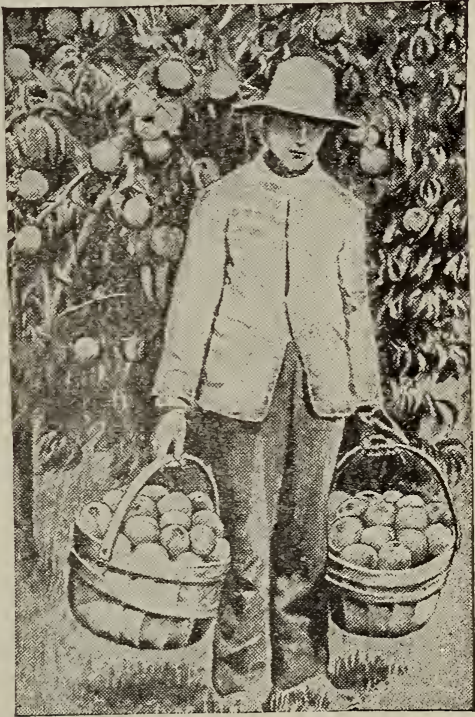

Price of Niagara peach trees is as follows: First-class orchard planting trees, largest size, 20c. each, $\$ 2.00$ per $12, \$ 15.00$ per 100 . Medium ${ }^{\circ}=2$ trees, $18 \mathrm{c}$. each, $\$ 1.80$ per $12, \$ 12.00$ per 100 . Small size trees, 2 to 3 feet, 12c. each, $\$ 1.25$ per $12, \$ 7.50$ per 100.

Engle's Mammoth-Large, round, suture slight; yellow, with red cheek; flesh yellow, stone small, free; sweet, rich, juicy. Sept.

Price of Englle's Mammoth and Greensboro: First-class orchard planting trees, 3 to 4 feet high, well branched, 15c. each, $\$ 1.25$ per $12, \$ 9.00$ per 100 . Price for selected size trees : $18 \mathrm{c}$. each, $\$ 1.75$ per 12 , $\$ 12.00$ per 100 . Small size trees, 2 to 3 feet, $10 \mathrm{c}$ each, $\$ 1.00$ per $12, \$ 6.00$ per 100 . 


\section{STTANDARD PEAR TREES}

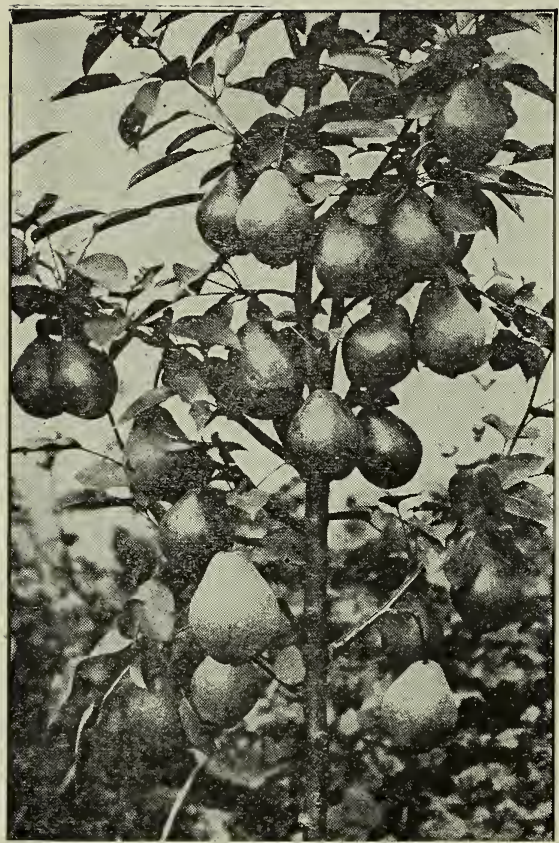

Price of Kieffer Pear (only) largest size, 6 to 7 feet, 18c. each, 50 for $\$ 7.50,100$ for $\$ 15.00$.

\section{KIEFFER HARDY WINTER PEAR}

KIEFFER PEAR, Standard and DwarfThe Kieffer has many admirers on account of its splendid growth of tree, productiveness, and selling well in market. For the home market this variety will not be a favorite with all, although some like the fruit, and everybody admires the tree, which is as good an ornamental tree as ever graced a lawn or door yard. One fruit grower said: "Owing to the question of quality he thought it would not sell, but the past season buyers ran after him and sought the Kieffer." Its looks sell it. He has I,6oo trees. Those ten years from the bud, were as large as Bartletts 25 years old. The fruit hangs on well and is not liable to be blown off, and is good to handle because it is hard when fit to pick. The Kieffer succeeds best as a standard.

Sheldon Pear-First quality; large, round, russet and red, melting, rich and delicious. Tree vigorous, erect and handsome, and bears well when grown. As a standard, should be more largely planted.

Lawrence - Late Winter Pear - Standard and Dwarf.-Size, medium to large, obovate; golden yellow; flesh melting, with a pleasant aromatic flavor. Tree a moderate grower and abundant bearer.

Price of Standard Trees for all varieties mentioned above except Kieffer. First-class 2 to 3 years, 5 feet high, 20 cents each, $\$ 2.25$ per $\$ 12, \$ 18.00$ per 100 . Extra size, 25 cents each, $\$ 2.50$ per $12, \$ 20.00$ per 100 , Small size trees, 4 feet high, 15 cents each, $\$ 1.50$ per $12, \$ 12.00$ per 100 .

See above bargain prices for the best Kieffer pear trees you ever saw.
Seckel P e a r St a n d a d and Dwarf. The standard of excellence in the pear, small, but of the highest flavor and production, and small Seckels sell better than large, if smooth and fair.

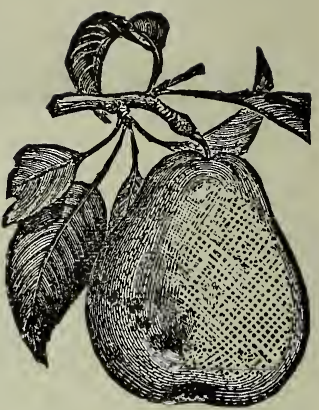

Anjou (Beurre d'Anjou)-Standard and Dwarf-A large, handsome pear, buttery and melting, with sprightly, vinous flavor; keeps into mid-winter. Tree a vigorous grower and a good bearer.

Clairgeau-Standard. Very large pyriform; flesh yellowish, nearly melting; keeps sound a long time after being gathered. Tree a free grower and early abundant bearer; a magnificent and valuable market fruit.

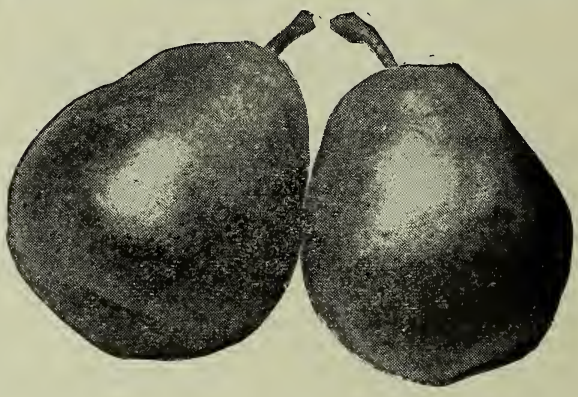

Duchess Pear-(Duchesse d'Angouleme)Standard and Dwarf. Trees of the Duchess are great yielders, and being vigorous growers are money makers. What the Bartlett pear is as a standard, the Duchess pear is as a dwarf. The Duchess tree has a vigorous and healthy growth, and bears uniformly heavy crops of large and attractive fruit. There is no pear in existence which outyields the Duchess. The fruit is prized as a dessert fruit or for cooking.

Wilder Early Pear pleases all because: First, it looks well; it is a good grower. Second, it produces a crop early; two-year graits at the nursery and trees four years old produce a lot of fruit. Third, the quality of the fruit is the best. Fourth, one does not have to wait until frost to get it. It ripens August Ist or before. yellow and red; handsome and attractive; 


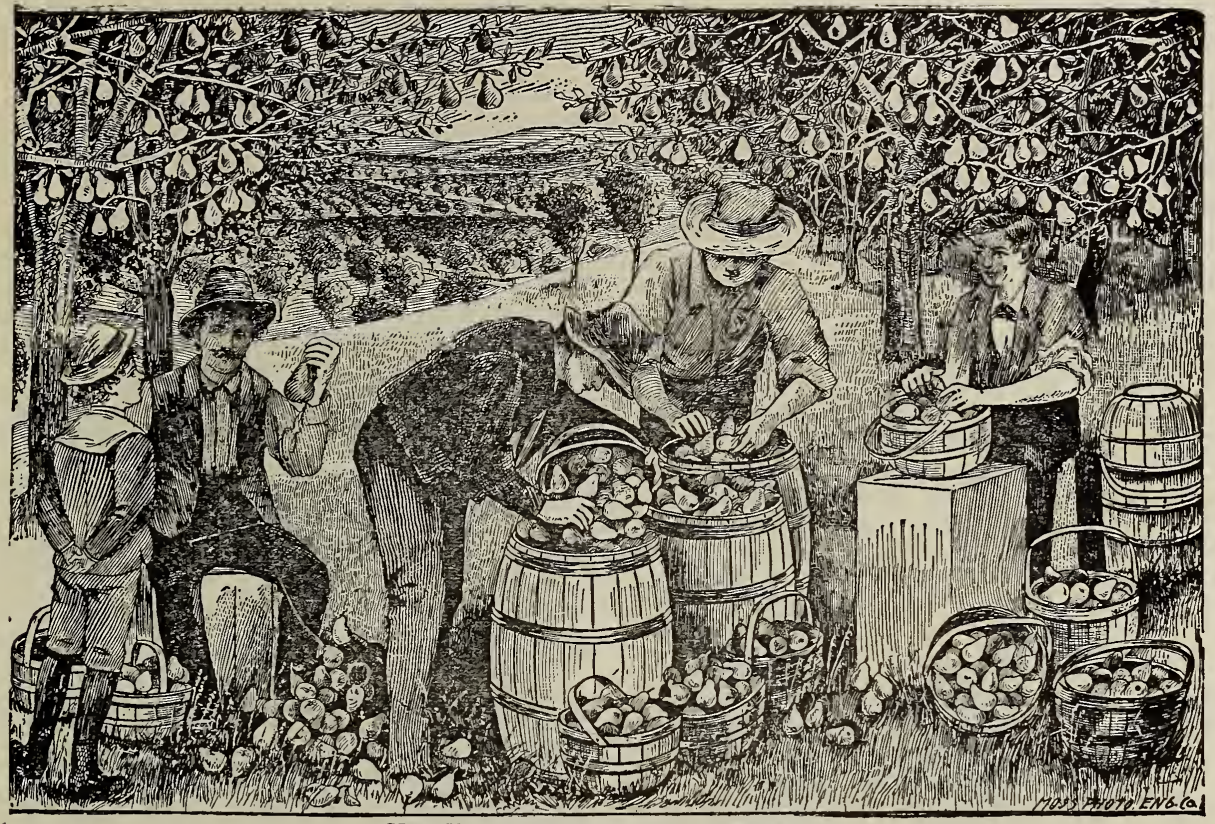

HARVESTING BARTLETT PEARS.

Bartlett Pear.-Successful as Standard or Dwarf. Dwarf Bartlett pears in C. A. Green's garden only 5 feet high were filled with beautiful specimens. What the Concord is among grapes, the Baldwin among apples, the Crawford among peaches, is the Bartlett among pears. It is the most popular pear, both for home use and market, that the world has ever known. It is buttery and melting, with a rich, musky flavor. The tree is vigorous and rapid in growth. Its season is September. Many people remove half of the fruit in August, ripening this for market, thus relieving the tree of its strain and securing larger fruit from that which remains on the tree. As the Bartlett is liable to overbear, nearly half of the fruit should be removed early in the season when about the size of a hickory nut. If this is done and the trees are kept in cultivated soil and well fertilized, they will bear profitable crops of the finest specimens imaginable. All pears should always be picked before fully ripe to secure best quality.

Price of Standard Bartlett : First-class trees, 2 to 3 years, 5 feet high, 25c. each, $\$ 2.50$ per $12, \$ 20.00$ per 100. Extra size, $30 \mathrm{c}$. each, $\$ 3.00$ per $12, \$ 24.00$ per 100 . Small size trees, 4 to 5 feet high, $18 \mathrm{c}$. each, $\$ 2.00$ per $12, \$ 15.00$ per 100 .

Clapp's Favorite Pear.-Standard and Dwarf. Season, August, earlier than Bartlett.

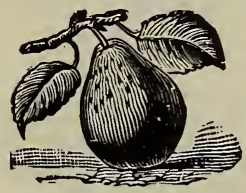

This is without doubt the most productive pear in cultivation. Every limb is a veritable rope of pears. A splendid pear resembling the Bartlett and ripening a few days earlier. A cross between Bartlett and Flemish Beauty; the tree is hardy and vigorous, either as standard or dwarf. Care should be taken to pick the fruit ten days before it ripens upon the tree. This pear is very large, remarkably beautiful and a prolific bearer. No collection is complete without it. Larger than Bartlett and has a handsome red side.

Price of Standard Clapp's Favorite Pear : Firstclass trees, 2 to 3 years, 5 feet high, 25c. each, $\$ 2.50$ per $12, \$ 20.00$ per 100 . Extra size, 30c. each, $\$ 3.00$ per $12, \$ 24.00$ per 100 . Small size trees, 4 to 5 feet high, $18 \mathrm{c}$. each, $\$ 2.00$ per $12, \$ 15.00$ per 100.

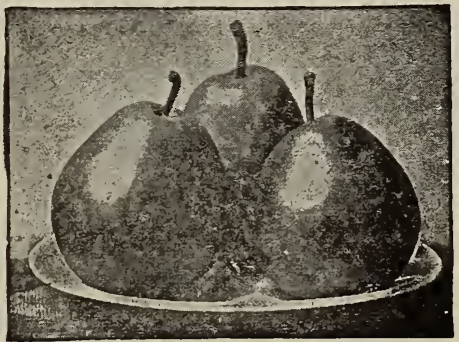

Flemish Beauty.-A large, beautiful, melting sweet pear. Tree very hardy, vigorous and fruitful; succeeds well in most parts of the country. Needs an open sunny location on well drained soil for best results. Season September and October.

Price of Standard Flemish Beauty: First-class trees, 2 to 3 years, 5 feet high, 20c each, $\$ 2.25$ per $12, \$ 18.00$ per 100 . Extra size, 25c. each, $\$ 2.50$ per $12, \$ 20.00$ per 100 . Small size trees, 4 feet high, 15c. each, $\$ 2.00$ per $12, \$ 12.00$ per 100 . 


\section{STANDARD PEAR TREES}

Gans Seedling Pear, New-This valuable summer pear was sent us by the originator, who is an old friend and patron, six years ago. This has given us time to fruit the pear at Green's fruit farm and to test its merits. Our C. A. Green is greatly pleased with it. It is a valuable early variety of high quality. Ellwanger \& Barry describe it as follows : "'A fine early pear, ripening just after Tyson arid a week or ten days before Bartlett."

Price of Gans Standard trees: Medium size, 2 years, 35c.each. Large size, 50c. each. Price of Dwarf trees of Gans pear, 30c. each.
Worden-Seckel Pear-This is a seedling of the Seckel, which it resembles and fully equals in flavor and quality, and far surpasses in size, color, form and beauty.

Price of Worden-Seckel Standard medium sized trees, 50c. each; small size trees, 25c. each. Dwarf trees, medium size, 25c. each, large size, 45c. each.

Bosc Pear-Finest quality, large as Bartlett, very productive.

Price of Bosc pear trees: Strong, 2-year planting size, 50c. each; small size trees, 25c. each.

\section{PLANT DWARF PEAR TREES IN HEDGE ROWS.}

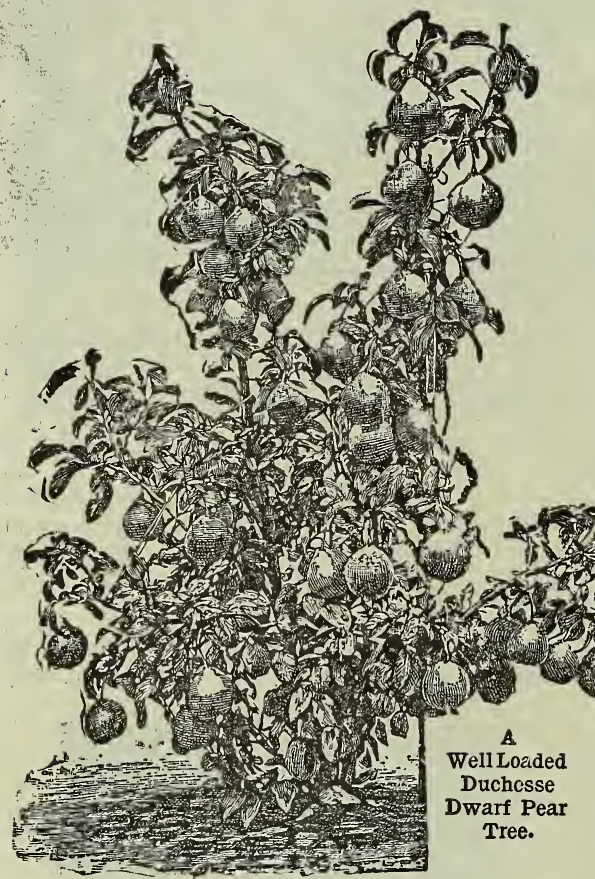

Duchess Pear-(Duchesse d'Angouleme). A fruit grower writes me that Duchess dwarf pear trees give uniformly large crops of pears of marvelous size and good quality. He says that in his locality the Duchess is grown more largely than any other, several growers having from three to ten acre orchards, and they find it a profitable fruit. Trees of the Duchess are great yielders, and being vigorous growers are money makers. What the Bartlett pear is as a standard, the Duchess pear is as a Dwarf. The Duchess tree has a vigorous and healthy growth, and bears uniformly heavy crops of large and attractive fruit. There is no pear in existence which outyields the Duchess. The fruit is prized as a dessert fruit or for cooking. Like all
Dwarf pears, it should have the branches of the last season's growth cut back at loast one-half every fall or in the spring before the growth begins.

Dwarf Pears should be planted so that the point where the bud is on the quince root be two inches below the surface of ground. Standard trees should be set so that in their new position they are a little deeper than they were before they were taken from the nursery row. The fruit should be picked when the stem will part readily from: the branch, without breaking. Pears shonld be ripened in a dark room and should not ie left to ripen fully on the tree. It will pay well to thin the fruit wherever it is too thick, and pull off any knotty or poor speciniens. This should be done at different times during the summer.

Dwarf Pear Trees bear at an early age, often bearing the second year after planting. They occupy but little room, and yield superior specimens of fruit and an abundance of it. Dwarf pear trees should be kept cultivated, and yet I have seen dwarf pear trees bearing abundantly in sod ground that had not been cultivated for many years. But where the ground is not intended to be cultivated, ordinarily the standard pear tree will do better than the Dwarf tree.

Varieties of Dwarf Pears-We offer the following list of superior varieties of Dwarf pear trees. Bartlett, Gans, Clapp's Favorite, Duchess, Howell, Lawrence, Worden Seckle, Seckle, Howell Beauty, Flemish Beauty, Wilder Early.

Price of Dwarf Pear Trees: First class orchard planting trees, 18c. each, $\$ 1.75$ per 12, $\$ 12.00$ per 100. Extra large selected trees, 20c. eâch, $\$ 2.00$ per $12, \$ 15.00$ per 100 . Small size trees, $15 \mathrm{c}$. each. $\$ 1.50$ per $12, \$ 10.00$ per 100 . Except Bartlett Dwarf Pear Trees prices of which are: First-class orchard planting trees, 22c. each, \$2.25 per 12, $\$ 16.00$ per 100. Extra large selected trees, 24c. each, $\$ 2.50$ per $12, \$ 19.00$ per 100 . Small size trees, 19c. each, $\$ 2.00$ per $12, \$ 14.00$ per 100 .

If a quantity of Duchesse alone are wanted ask for special pen prices. 


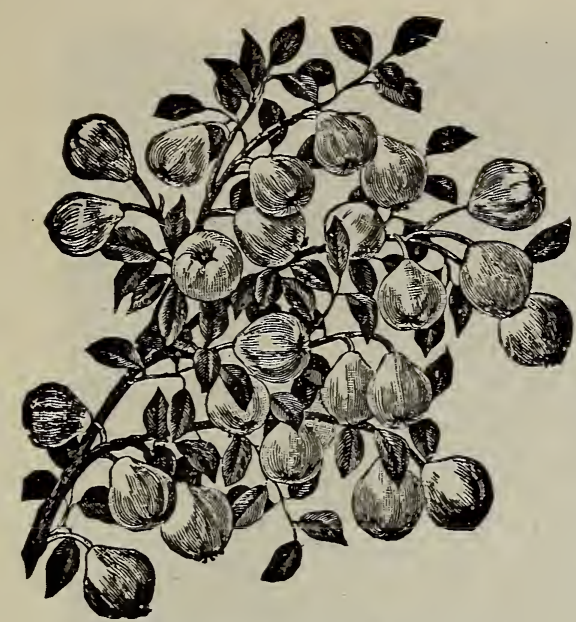

ORANGE QUINCE VERY PRODUCTIVE

\section{QUINCE CULTURE.}

The quince could be judiciously grown for its beauty alone. Nothing could be more attractive than a bush of this quince in fruit or in blossom. The fruit remains on the tree a long time after coloring, before ripe enough to gather, hence being desirable for that reason, as an ornament. But it is for its excellence as a canning fruit, for marmalades and jellies, that the quince is especially esteemed. It possesses a flavor peculiar to itself and unknown in all other fruits. Choice fruit of the quince is ever in demand at paying prices.

Meech's Prolific Quince-This variety is holding its good name and pleasing all who are fruiting it. It is rightly named prolific, being prolific in growth, prolific in yield and prolific in all good fruit points that go to make up a good fruit.

Orange Quince-Every one is well acquainted with the Orange quince, a good old variety that never disappoints the plantergood for home use and for market, and more largely planted than any other variety. Its large, golden yellow fruit of fine quality is to be seen in more or less quantities in nearly every garden or orchard every season, as it rarely fails to produce a crop.

Bourgeat Quince-This is the most remark-

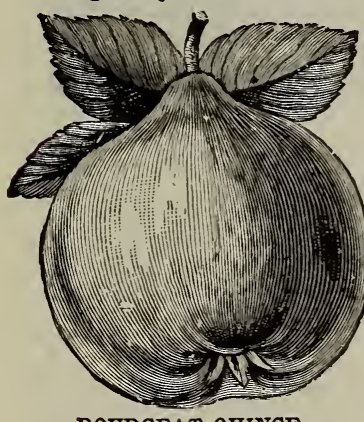
able of all the quinces. There is no other varietywhich grows so vigorously, and there is no other variety of the quince which will keep so long in perfect condition. Trees of $t h$ is quince grow as rapidly as an apple tree and attain the size and shape of an apple tree, while most quinces grow in the form of a bush. The Bourgeat quince bears at an early age, producing large crops of exceedingly large and handsome fruit, of a rich golden color. While it ripens soon after the Orange it keeps till past midwinter when desired, or it is ready to use at once on maturity. This is a remarkable characteristic, since ordinary quinces are of a perishable nature. The crop can be held in the hands of the grower or in the hands of the purchaser until the market suits his fancy. It has so far proved to be free from leaf blight, the leaves keeping green until killed by frost.

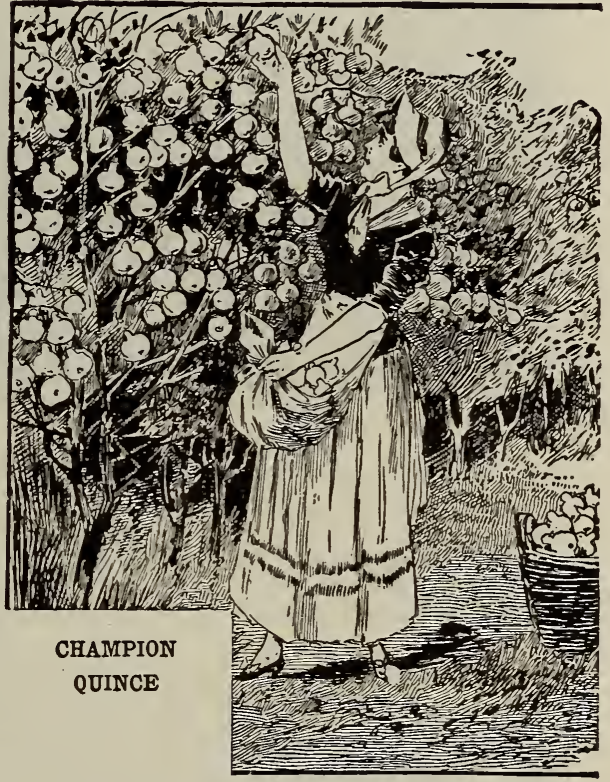

Champion Quince-This is a large fruited quince. Color, bright yellow; flesh tender and most excellent for making preserves, jellies, marmalades, etc. Champion quince has a delicate flavor peculiar to itself. The trees are vigorous growers and bear heavy crops of superior fruit. The peculiarity of this quince is that it yields fruit on very young trees soon after planting. The fruit keeps well and ships well. Notice that quince trees are scarce this year all over the country. The fact is, that genuine varieties correctly named can scarcely be found anywhere.

Price of all varieties of Quinces on this page: First-class bushes, 3 to 5 feet high, $50 \mathrm{c}$. each, $\$ 4.50$ per 12. Small size bushes, 3 feet high, 35 . each, $\$ 3.50$ per 12 . 


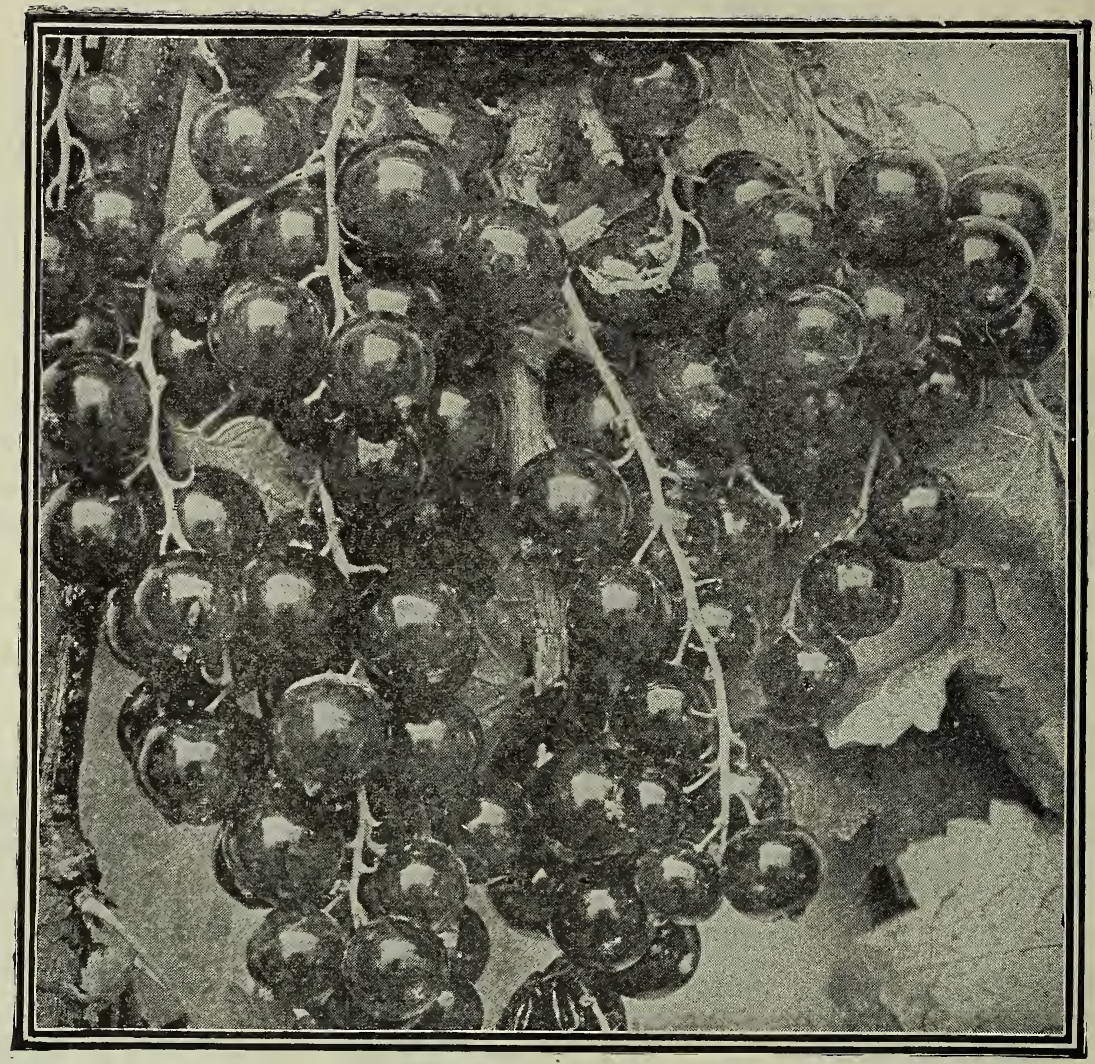

\section{DIPLOMA GOLD MEDAL CURRANT}

DIPLOMA is a late red currant, the largest of any variety that I have ever seen, originating with the veteran Jacob Moore, who originated Red Cross currant, Diamond grape, Brighton grape and Bartlett Seckel pear. It is named Diploma for the reason that it received a diploma for the largest and best currant at the Chicago World's Fair and was awarded a gold medal at the exhibition. Diploma is a vigorous grower and a very productive variety. Like the Red Cross it is not so acid as Cherry and is a little lighter in color, but it is a bright red, attractive currant. It makes excellent jellies and will make a very profitable commerical variety, also be desirable for the homegarden. This currant was awarded a gold medal and diploma at the Columbian Exposition at Chicago, also a medal and diploma at the Pan-American Exposition at Buffalo, N. Y.-C. A. GreEN.

Price of Diploma Currant, strong 1-year-old bushes $8 \mathrm{c}$. each, $80 \mathrm{c}$. per 12 . Strong 2-year-old bushes $10 \mathrm{c}$. each, $\$ 1.00$ per 12,50 for $\$ 4.00$.

Red Cross-Price of Red Cross, strong, 2-year-old bushes, 60c. per 10, $\$ 5.00$ per 100, $\$ 45.00$ per 1,000. Strong, 2-year old No. 2 bushes, and strong 1-year-old bushes 50c. per 10, $\$ 4$ per 100, $\$ 35.00$ per 1,000 .

Pres. Wilder-Price of Red Pres. Wilder : 2 years 01d, 60c. per $10, \$ 5.00$ per 100.

White Grape-Price of White Grape Currants : 2 year old, 60c. per doz., $\$ 5.00$ per 100 .

Fay's Prolific-Price of Fay's : 75c. per 12, $\$ 5.00$ per 100 for two year old plants.

Champion Black-Price, 2 years old, 75c. per $12, \$ 5.00$ per 100.

Victoria and Cherry-2 years, 75c. per $12, \$ 5.00$ per 100.

\section{SEE BACK OF COLORED PLATE FOR OUR SPECIAL OFFERS AT SPECIAL PRICES.}




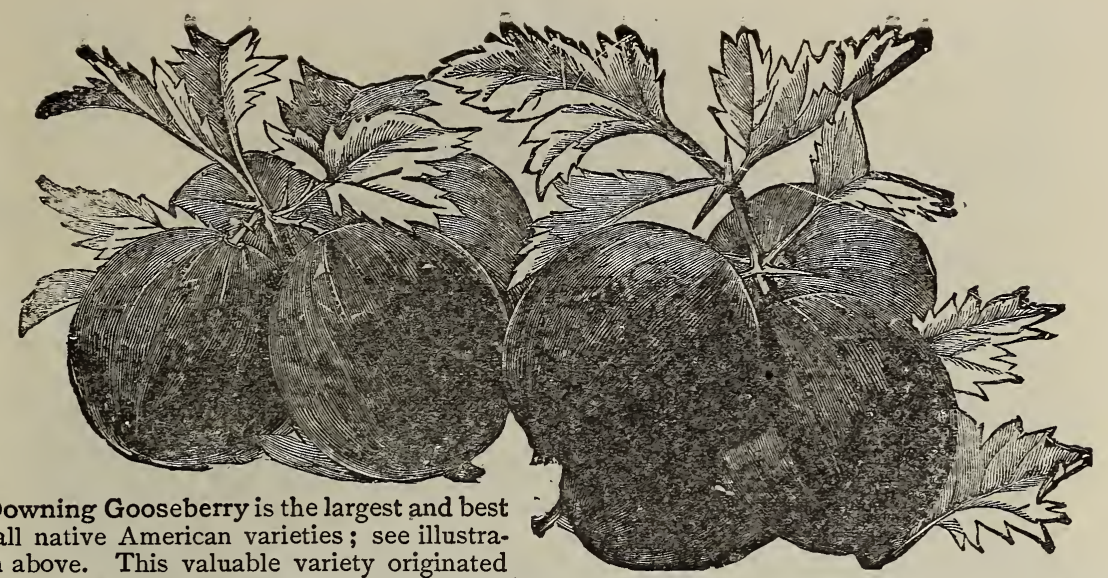

tion above. This valuable variety originated

with Charles Downing, greatest of all pomologists. The value of Downing lies in its large size, fine quality, beautiful appearance, vigorous growth, and freedom from mildew. This variety is recommended as proof against mildew. Downing is free from spines, of a transparent color, tending to yellow ; bush upright, keeping the fruit from the sand. Downing is enormously productive. Surely planters of gooseberries have overlooked the great value of the Downing. Since plants of Downing can be produced in America, and plants of foreign varieties cannot, Downing plants can be sold at a lower price, which is another inducement for planting. In order to make the Downing gooseberry known to our patrons we mark herein perhaps the lowest price ever made for such strong, vigorous plants. An acre of Downing can be made to yield $\$ 500$. It is unsurpassed for canning. It is easily harvested by stripping the branches with a gloved hand, enabling the picker to gather many bushels in a day. The winnowing of leaves is done by an ordinary fanning mill, the same as beans. They can be shipped from Maine to California like marbles.-C. A. GreEN.

Price of Downing Gooseberry : 2-year-old bushes, first-class, 10c, each, $\$ 1.00$ per $12, \$ 7.00$ per 100 .

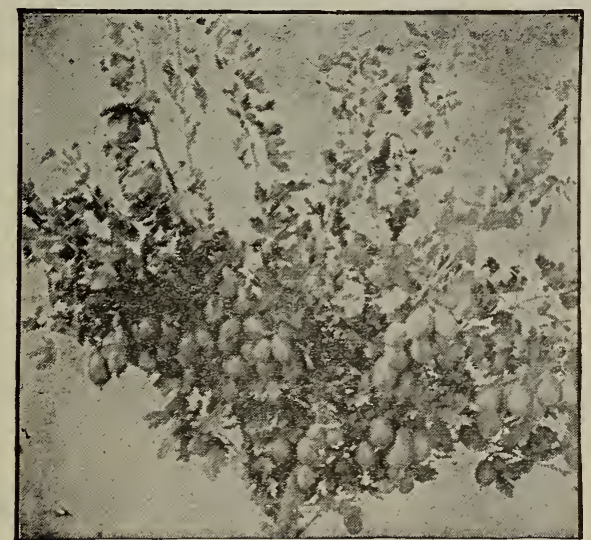

Industry Gooseberry-This is a large red English variety which has succeeded better in this country than any other foreign variety. It is very productive and the fruit is of superior quality, selling well in the market and being desirable for family supply. It will succeed better when partially shaded by a fence or tree.

Price 20c. each, $\$ 2.00$ per 12 , for strong 2-yearold bushes.

Price of Red Jacket Gooseberry : 2-year bushes I5c. each, $\$ 1.50$ per $12, \$ 12.00$ per 100 .

GREEN'S GUARANTEE.-We will replace free or refund the amount paid us for any stock not true to name but are not liable for other damages. All shipments travel at the risk and cost of purchaser.

\section{PLUM TREE COLLECTION NO. I}

\section{TREES FOR $\$ 1.98$.}

Shipper's Pride, 3 Burbank

I Beauty of Naples, 2 Lombard,

I Red June, 2 Gueii,

I Thanksgiving, 2 Iive-Forever Rose Bushes. All trees. I,argest size 6 to 7 feet high.

12 PLUM TREES, SPECIAL BARGAIN PRICE \$1.98

\section{PLUIM COLLECTION NO. 2}

\section{TREES FOR $68 \mathrm{c}$}

2 Burbank,

2 L,ombard,

I Thanksgiving, I Reine Claude. All trees of medium size, 4 to 5 feet high, 2-years

6 PLUM TREES, SPECIAL BARGAIN PRICE 68c.

\section{Green's Big Plum Collection No.999}

20 PLIUM TREES FOR $\$ 3.24$
5 Burbank,
3 Lombard,
3 Bradshaw,
2 Red June,
I Beauty of Naples,
2 Shipper's Pride,
2 Thanksoiving, 2 Gueii.

4 Live-Forever Rose Bushes.

All largest size trees 6 to 7 feet high, f. o. b. here 20 PLUM TREES, SPECIAL BARGAIN PRICE \$3.24

\section{STRAWBERRY PLANTS}

Varieties grown and offered by us Corsican Senator Dunlap, Brandywine, Pineapple Flavored and Cardinal. Strong heavily rooted fresh dug plants that are sure to please and grow. Price of layer plants, 25c. per $12,75 \mathrm{c}$. per $100, \$ 6.00$ per 1000. 


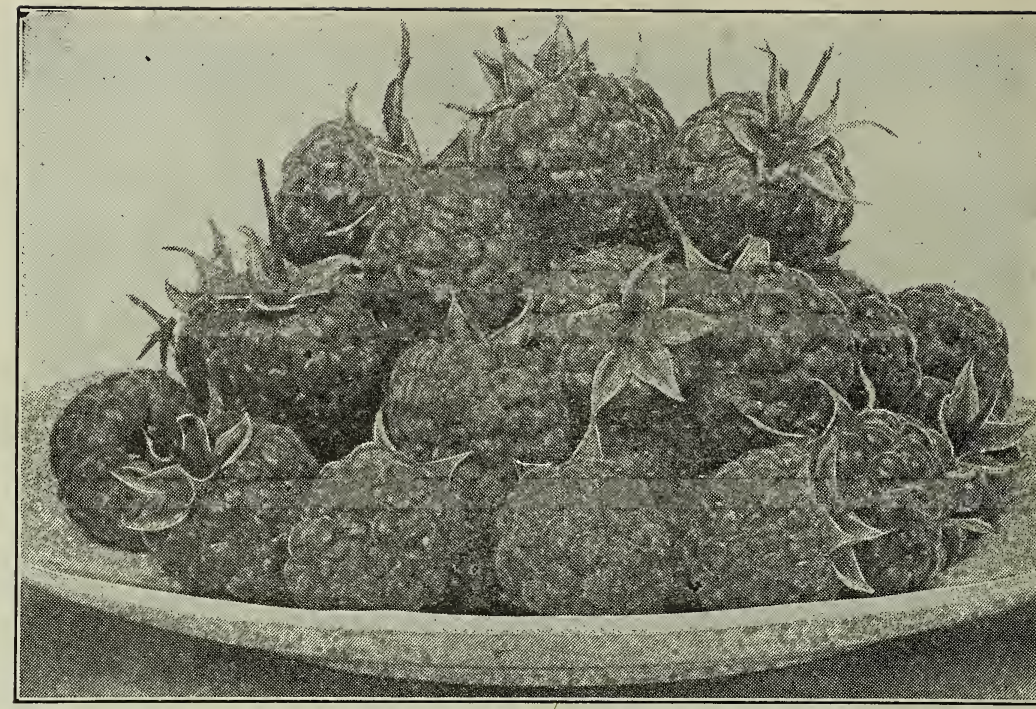

\section{THE NEW BRIGHT RED RASPBERRY SYRACUSE}

C. A. Green says that this is the greatest and most valuable raspberry the world has ever seen. It is the largest of all bright red raspberries. Its flavor is of the highest grade. It is remarkably attractive and continues in bearing for over a month, but best of all it is perfectly hardy in Rochester during the most severe winters we have known. We have never given it any winter protection and it has never been injured by the most extreme cold weather.

This new SYRACUSE Raspberry is not new to us, as it has been growing extensively at Green's fruit farm for the past eight years. It has taken us eight years to secure a moderate stock of plants owing to the fact that this bright red raspberry does not make new plants freely as does the Cuthbert, therefore plants of the Syracuse will never be sold at a low price. The fact that this raspberry propagates from suckers, but makes few plants, is in its favor for those who plant it in garden or field for fruit. The fact that some red raspberry plants multiply rapidly by suckers is a curse rather than a blessing, for the plants soon get so thick along the rows that they will not produce good fruit. Owing to the fact that the Syracuse does not multiply rapidly, a row of plants or a plantation will continue in bearing for twenty years without renewing, if the ground is fertilized. The Syracuse is a vigorous grower and we are satisfied it will more than please our patrons. You may prepare yourself to be surprised when you see its large, beautiful fruit, and the abundance of it on such plants as you set out on your place. Remember that the price of these plants will never be low. C. A, GREEN.

\section{GREEN'S NURSERY COMPANY :}

We are in receipt of the sample of your new red raspberry named Syracuse, and regard it as most promising, it being large and handsome and of good quality.

\section{ELIWANGER \& BARRY.}

The price at present of Syracuse Raspberry is $\$ 1.00$ each by mail or express. See prices of plants and trees sent by mail postpaid on last pages.

Windsor Cherry is very late and is more valuable than others on that account. Windsor ripens on our grounds 16 days later than Gov. Wood. The early cherries are good for home use but the Windsor is more valuable for marketing. The Earlier Sweets sold at 4 to $5 \mathrm{c}$ per pound. The Windsor at 7 to 8c. The earlier varieties ripen the bulk of their crop with strawberries and this is a poor season for the shipper. We recommend the Windsor on account of its large, sweet, firm flesh, but especially on account of its. late ripening.

Price 35c each for largest trees. Medium sized trees 25c. each. Smaller, 20c. each. See page 28 for furtber description and other cherries.

\section{GREEN'S CHERRY COLLECTION.}

The Montmorency hardy red cherry, and Early Richmond hardy cherry are among the most valuable of the hardy cherries which succeed every where in this country. C. A. Green offers 2 English Morrello, (late), 2 Green's Black Tartarian, I Windsor, (Black) I Yellow Spanish, 3 Montmorency and 3 Early Richmond cherry trees, all 5 to 6 feet high, firstclass in every way, all carefully $\$ 3.00$
dug and packed, I2 trees, for

Diploma Gold Medal Currant-See page 37 for illustration. This is the greatest currant on earth and the most productive. Notice that the price has been greatly reduced in this catalogue. 


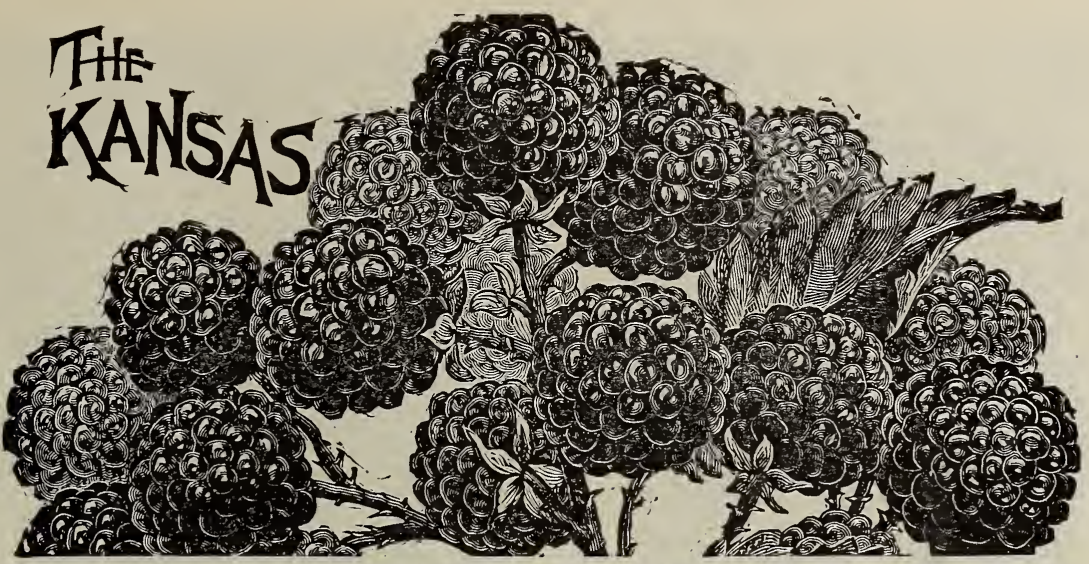

Kansas Black Raspberry.-Is of the largest size, vigorous, healthy and productive. It is a leading favorite at Green's fruit farm. When I was a boy I delighted to gather the wild black raspberries, but in those days I never met with anything like the Kansas. Fruit is large and excellent in quality. We have fruited it several seasons and find it an excellent variety.-C. A GreEn.

Price of Kansas Raspberry, 35c. per 12, \$1.50 per 100, \$14.00 per 1000.

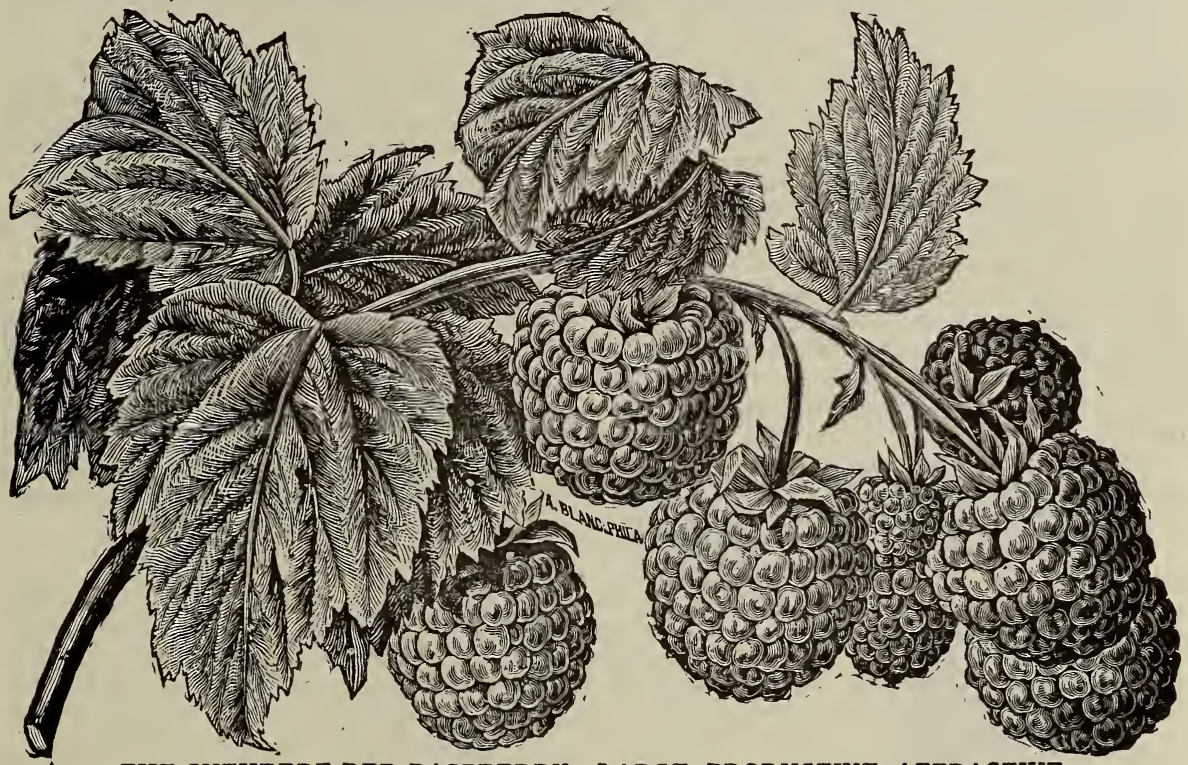

THE CUTHBERT RED RASPBERRY. LARGE, PRODUCTIVE, ATTRACTIVE.

This is a valuable variety well tested throughout the country. It has given good results both for home use and market. When it was introduced the demand for plants was far beyond the capacity of any one to supply, and it marked a new era in raspberry growing. Previous to the Cuthbert, red raspberries were a novelty in the market and sold at from fifteen to twenty-five cents per quart. Cuthbert was largely planted, and it succeeded so well as to bring about a lower price for the fruit, which for a time discouraged planters. But the last year or two there has been a great scarcity of red raspberries, and the price has again advanced so that this year the price opened at twenty cents per quart, and did not go lower than fifteen cents per quart even at Rochester, where red raspberries are largely grown. Cuthbert is a good vigorous grower and possesses vitality necessary for a popular variety. It yields bountifully of large and beautiful bright red berries, which are easily picked and always command good prices. No fruit grower can afford to omit planting Cuthbert, and surely no person who has a garden should attempt to get along without red saspberries.

Price of Cuthbert raspberry plants, 50 cents per $12, \$ 1.25$ per $100, \$ 9.00$ per 1000 .

Ruby Red Hardy Raspberry, new, larger and better than Cuthbert, price 50c. per 12. $\$ 2.50$ per 100 . 


\section{BLACKBERRIES}

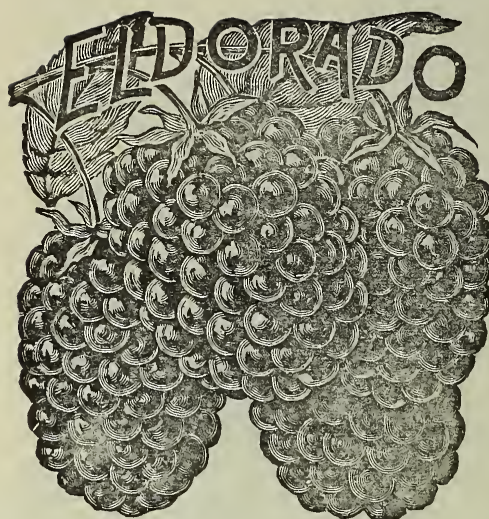

Eldorado Blackberry.-The hardiest and sweetest blackberry. At Green's fruit farm this variety has never winter-killed or failed to produce a full crop of the finest fruit. The vines are very vigorous and hardy. Berries are very large, jet black, borne in large clusters, and ripen well together; are very sweet, melting, pleasing to the taste, have no hard core, and keep eight to ten days. $\quad$ C. A. GREEN.

"The Eldorado is the most promising of the newer hardy blackberries. It appears to be as hardy as Snyder, and is larger and of better quality."-Ohio Experiment Station.

"From last year's experience I can say that the Eldorado is an immense producer, the berry ripens evenly and is very sweet, medium in size, second early. The yield was much greater than that of any other variety on our grounds last year."-Geo. C. Butz, Horticulturist State College, $P a$.

Price of Eldorado Blackberry, 65c. per 12, $\$ 3.00$ per $100, \$ 25.00$ per 1000 .

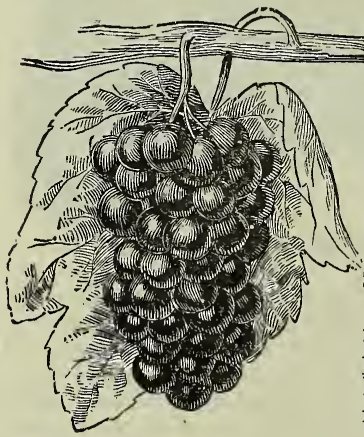

\section{NIAGARA HARDY WHITE GRAPE}

Popular everywhere. Bunch very large and handsome, often shouldered, conıpact; berries large, round; skin thin, tough, does not crack and carries well; has not much pulp when fully ripe, melting, sweet, with a flavor and aroma peculiarly its own, and agreeable to most tastes ; ripens with Concord, sometimes a little earlier. Vine very vigorous and productive, succeeding well in all sections. Is largely planted by. vineyardists.

Price of Niagara Grapes, 2-year-0ld vines, 10c. each, $\$ 1.00$ per 12 , $\$ 7.00$ per $100, \$ 50.00$ per. 1,000.

Regal Long Keeping Red Grape-If you want the longest keeping grape, one that you can eat during fall and winter months, plant the Regal. Its quality is equal to Catawba or U1ster. Regal grape keeps well owing to its tough skin and persistent nature, keeping in fine condition late in the season. I believe it will be a good shipper. C. A. Green says it is splendid for home or market. Good in every way and a long keeper.

Price of 2-year vines of Regal Grapes, $25 \mathrm{c}$. each, $\$ 2.50$ per 12.

\section{WHAT A BANKER SAYS ABOUT US}

CAPITAL AND SURPLUS \$1,000,000

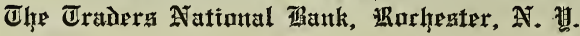

November 19, 1907,

To WHOM IT MAY CONCERN

I take great pleasure in saying that I consider Green's Nursery Company entirely reliable, a house of many years' standing, and with undoubted business integrity and honesty.

I believe any merchandise purchased from them will be found strictly according to contract, and true to nanie.

We have known the officers for many years past, and our business relations have been entirely satisfactory. The company has ample capital for the business done, and we and our business relations have been entirely satisfactory. The company purchase trees, shrubbery or other nursery stock. 


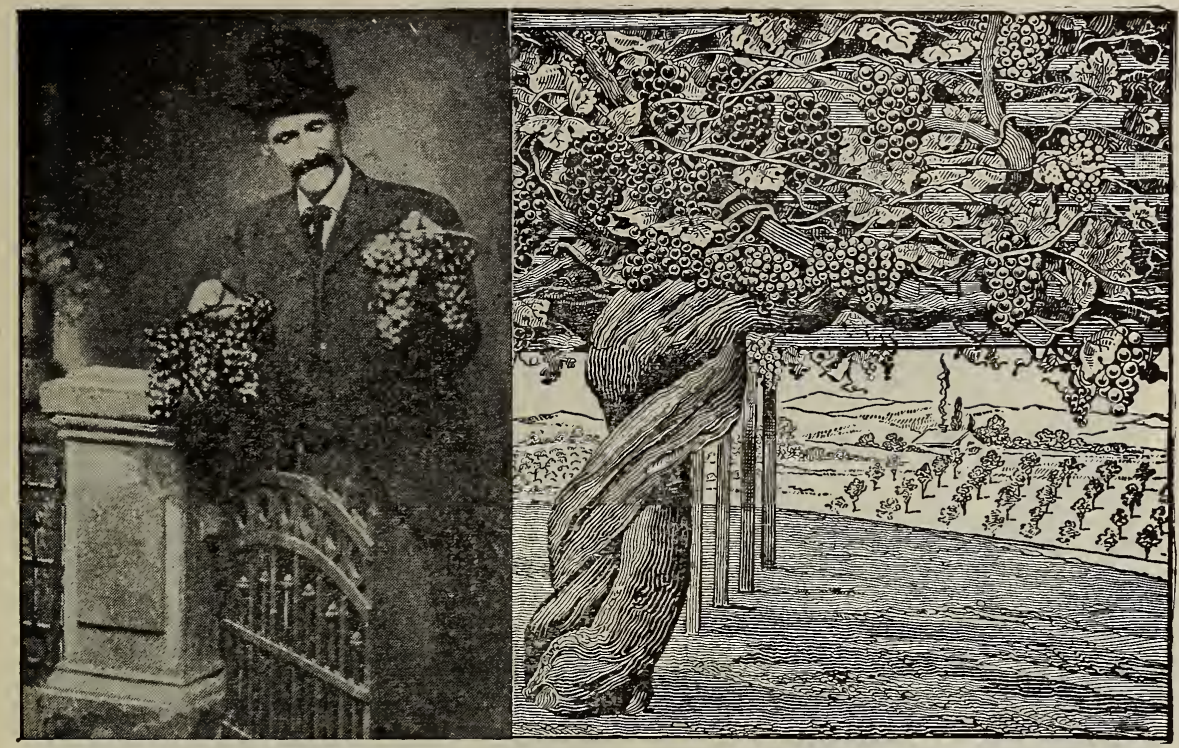

\section{CONCORD-Monarch of Hardy Grapes.}

Concord Grape.-This hardy black grape is decidedly the most popular grape in America, and deservedly so. Bunch large, shouldered, compact; berries large, covered with a rich bloom; skin tender, but sufficiently firm to carry well to distant markets; flesh juicy, sweet pulp, tender; vine a strong grower, very hardy, healthy and productive. For general cultivation the most reliable and profitable variety.

\section{Price of Concord Vines : 2-year, 10c. each, $\$ 1.00$ per 12, $\$ 7.00$ per 100, $\$ 45.00$ per 1000 .}

Worden Grape.-If you fail to plant Worden grape you will make a mistake. When it was first introduced it was claimed to be the same as Concord, since it resembles Concord in many respects. It is, however, much earlier than Concord in ripening and larger in size of berry. Its earliness of ripening is a strong point over Concord. It will not ship, however, so well as Concord, being tender in skin, but for home use I know of no grape of greater value.

Everyone plants it. It is an enormous crenper and its vines are vigorous enough to ripen such crops, but the more fruit a vine carries the later will it ripen its fruit. Worden is ripe and gone before Concord comes in. It is an early black grape, very large in cluster and berry, of good quality, selling well everywhere. In brief, Worden is an improved Concord, being larger in both bunch and berry, handsomer, nearly two weeks earlier, and of better quality. Surely this is enough to please all. If only one grape vine can be planted, plant the Worden.

Price of Worden Grape : Strong vines, 2-year, 10c, each, $\$ 1.00$ per $12, \$ 7.00$ per $100, \$ 50.00$ per 1000 .

\section{GRAPE VINES AT A BARGAIN 12 VINES FOR 98c}

One-third off regular price. Must be sold

We offer 3 Worden, black; 3 Concord, black; I Campbell's Early, black; 2 Regal, red; 3 Niagara, white ; all 2-yearold, first-class grape vines for 98 cents, regular price being $\$ \mathrm{I} .35$.
Moore's Early.-Clusters of medium size ; berries large, round, black, with heavy blue bloom. Desirable for market on account of its earliness, well suited for Canada and northern portions of the United States.

Price of Moore's Early-2-years, 15 cents each, $\$ 1.50$ per $12, \$ 7.00$ per 100 .

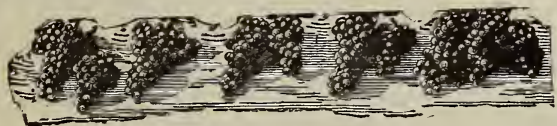

Diamond White Grape-This is our choice in white grapes. It is an excellent variety for those having only a small garden or those desiring to plant for market. In growth of vine it is marvelous and seems adapted to all localities where grapes are grown. It is a diamond among grapes. Extremely hardy; vine a vigorous grower; foliage large and healthy. Very prolific in bearing; cluster large and handsome.

Price: Diamond Grape, strong 2-year vines, 15c. each, $\$ 1.50$ per $12, \$ 10.00$ per 100 .

\section{ADDITIONAL VARIETIES}

Brighton-I5 cents each, $\$$ I. $5^{\circ}$ per I2. Campbell's Early - I 5 cents each, $\$$ I. 5 O per I2. Delaware-I5 cents each, $\$$ I.50 per I2. Diamond-I 5 cents each, $\$ I$. 50 per I2. Agawam-I5 cents each, \$1.50 per I2. McPike-Black, very large, 25 cents each. BARGAINS IN PLUM TREES See Page 4 


\section{ASPARAGUS THE BEST EARLY VEGETABLE.}

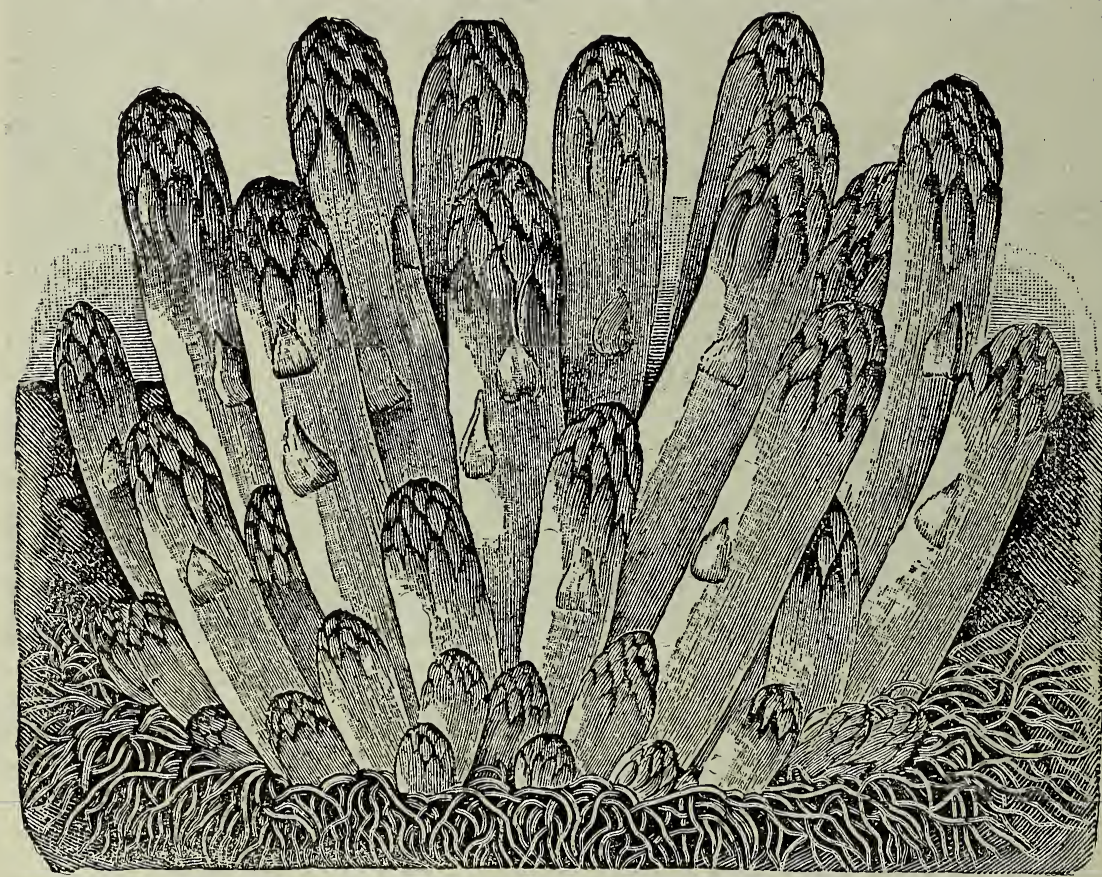

PALMETTO ASPARAGUS GROWING THE LARGEST STALKS READY TO CUT.

Palmetto Asparagus. - This is a large growing variety particularly delicious in quality. No home garden can be complete without it. Asparagus is one of the greatest garden delicacies, coming in at a season when there is no competitor. When once planted this will continue to produce abundantly for life. The plants late in the season are objects of great beauty, and are worth growing for their beauty. Palmetto Asparagus is valuable for its health-giving properties. It is also appetizing and is a rare delicacy for any table.

Conover's Colossal Asparagus. - This variety is known everywhere; is of large size, rapid in growth and of good quality. Grown on black muck land on our grounds at Clifton, it is mammoth in size and continues to give good cuttings for a long season. You will get more satisfaction out of a bed of this delicious esculent than any other vegetable. Asparagus is equal to a dish of early green peas. Coming as it does so early in the season, it is especially valuable for home use and for market.

Price of Palmetto and Conover's Asparagus: Strong 2 year plants, 30c. per 12,60c. per 100, $\$ 4.00$ per 1,000. Asparagus plants will be sent by mail postpaid at dozen rates, and in 100, if 20 cents is added to the 100 price.

\section{Rhubarb.-(Pie Plant).}

PRICE, extra strong roots, l(c. each, $\$ 1.00$ per $12 ; \$ 5$ per 100 , by express or freight.
Sage.-(Holt's Mammoth).

PRICE, large bushy plants that have been grown in the nursery row, each, $5 c$. 50c. per $12 ; \$ 3.00$ per 100 .

If Asparagus is desired by mail, add 20c. per 100 to prices given.

\section{GIVE PLAIN SHIPPING DIRECTIONS.}

State positively when ordering how we are to ship, whether by Freight, Express or Mail. If by Freight or Express, give name of R. R. Station and your Postoffice too. If by mail, your Postoffice only. Do not forget postage. If you desire shipped by a . special route, specify this also.

\section{IN WRITING US,}

Always give name, postoffice, county and state, with full particulars, and reference to previous correspondence, or orders, if any. Scores write us every season forgetting to do this. Please don't forget this! Some forget to sign their names or give postoffice or state. Make all orders PLAIN 


\section{THE CAROLINA POPLAR TREE.}

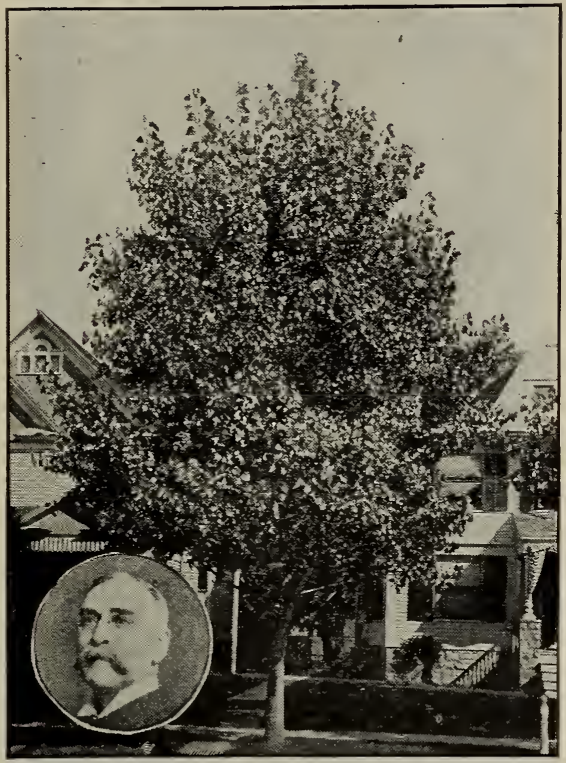

CAROLINA POPLAR TREE-BEST OF ALI POPLARS-PLANTED TWO YEARS.

This is the best, most beautiful and most desirable of all poplar trees. While a vigorous and rapid upward growing tree it does not shoot upward like a church steeple as does the Lombardy. The Carolina grows as rapidly as the Lombardy Poplar but it makes a more wide spreading tree. It is more like the maple or the oak, and is therefore more desirable as a shade tree and a wind break. The leaves of the Carolina Poplar are much larger than those of the Lombardy Poplar. Trees of the Carolina Poplar cost no more than that of the Lombardy Poplar and we recommend them with confidence to the patrons of the Green's Nursery Co. Carolina Poplar may be planted on the borders of a home lot or in a row Io or $12 \mathrm{ft}$. apart on the western border as a wind break. Every orchard needs a wind break and nothing is better and nothing grows more rapidly than the Carolina Poplar. You will want rapid growing trees to hide your barns and other outbuildings, so that they cannot be so plainly seen from the house and from the road. Nothing is better for this than the Carolina Poplar. Don't fail to notice that we offer these Carolina Poplar trees, 6 to 8 feet high at 20c. each, $\$ 2.00$ per 12 , and $\$ 12$ per hundred. Remember it is not necessary to buy the large trees of the Carolina Poplar since they grow so rapidly. Medium size trees are as desirable as the large size and freight can be saved in buying moderate sized trees.

Our C. A. Green says of Carolina Poplar: For a quickly growing shade tree, there is no tree which equals the Carolina Poplar. It is broadly pyramidal in form, very robust in growth, with large, glossy, deep green leaves. It stands the smoke and dust of the city streets better than any. other shade tree. Very useful for planting as a screen to shut out unattractive buildings.

Price of Carolina Poplar trees 10 to 12 feet high, 30 c. each, $\$ 3.00$ per $12, \$ 20.00$ per 100.8 to 10 feet, 25c. each, $\$ 2.50$ per $12, \$ 15.00$ per 100 . 5 to 6 feet 15c. each, $\$ 1.50$ per $12, \$ 10.00$ per 100 . 6 to 8 feet, $20 \mathrm{c}$. each, $\$ 2.00$ per $12, \$ 12.00$ per 100.

\section{Ruby Red Raspberry-} This new hardy red rasp berry has been well tested at Green's Fruit Farm where we have grown it for marzet for several years. It is larger, a better grower, and yields more quarts per acre than Cuthbert

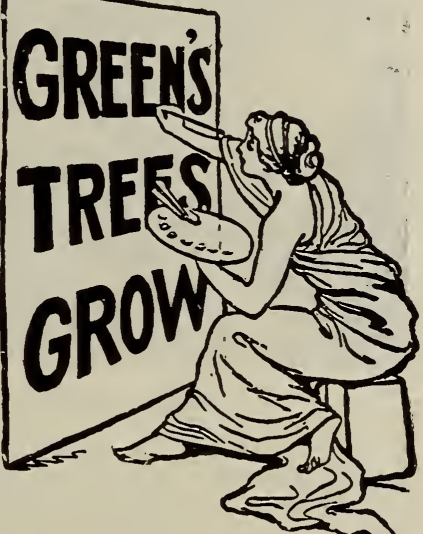
which is saying a good deal. C. A. Green says do not fail to plant the Ruby Raspberry.

Price 50c. per 12, \$2.50 per hundred.

Lombardy Poplar known everywhere, owing to its tall, pyramidal growth. This tree has been largely planted. These trees are often desired for planting in front of objectionable out-buildings, or to screen unsightly outlooks.

Price of Lombardy Poplar Trees : 6 to 8 feet, 20 c. each, $\$ 2.00$ per 12 . 8 to 10 feet, 35c. each, $\$ 3.50$ per 12.

Norway Maple-This is one of the hardiest ornamental shade trees, and of the most beautiful. It makes more of a wide spreading tree than the sugar maple. Price of Norway Trees : 8 to 10 feet, $75 \mathrm{c}$. each, 6 to 8 feet, $50 \mathrm{c}$. each.

Thorn, Double White-Has small, double white flowers. A highly ornamental variety, on account of both foliage and flowers. It makes a very striking contrast when planted with the double scarlet.

Price of White Thorn Trees, 50c. each.

Thorn, Paul's Double Scarlet-Flowers are bright carmine red. Superior to any of its color. Price of Red Thorn Trees, 50c. each.

For apple trees see page 26. For Sweet Chestnut see page $42-30 \mathrm{c}$. to 50c. each. Ruby Red Raspberry - new, large, fine, see page 42. For Golden Glow see page I. 


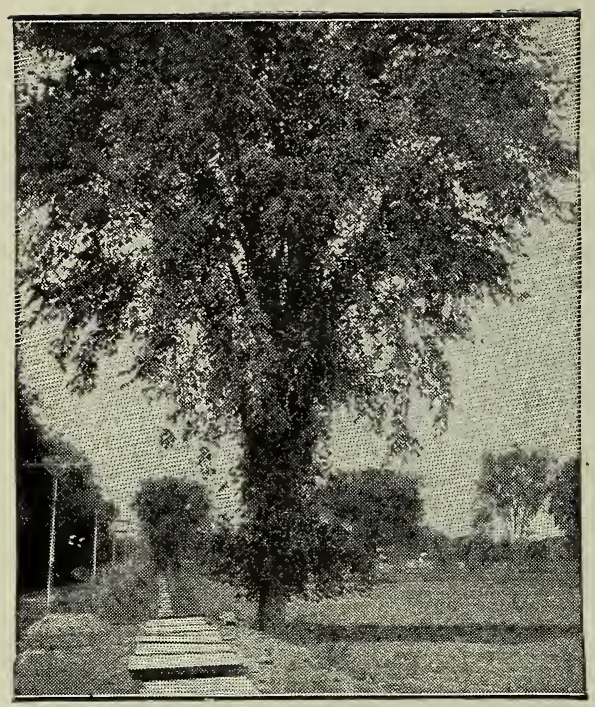

AMERICAN ELM.

American Elm- The most admired of all American trees. It is very attractive in any suitable location, is entirely hardy and easily transplanted. There are more Elm trees planted along our streets and highways than any other one variety. This on account of its dense green foliage, which spreads out from overhead, covering a suitable space of ground in proportion to the size of the tree, which makes it the finest shade tree in the world. We have a large stock of these handsome and most beautiful trees.

Price of American Flm : First-class trees, 6 to 8 feet high, $35 \mathrm{c}$. each, $\$ 3.50$ per $12 ; 8$ to 10 feet high, 50c. each, $\$ 5.00$ per 12 .

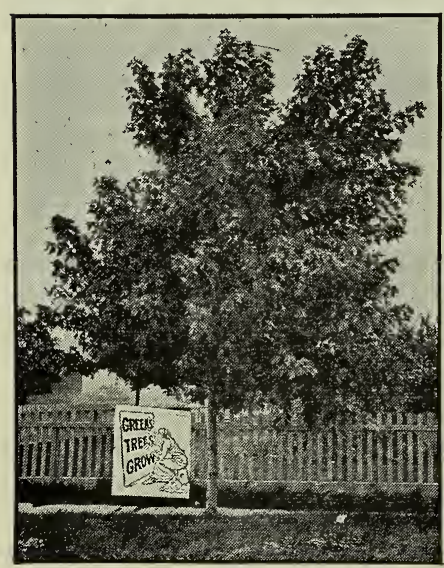

Silver Maple one of the bestquick gro wing s h a d e trees. It is beautifully ornamental if - given room to develop, and is particularly useful on very wide streets and avenues. Fo-

SILVER MAPLE TREE liage is of an attractive silvery tinge. Succeeds well on all soils. Price of Silver Maple trees: 8 to 10 feet, 50c. each, $\$ 5.00$ per $12 ; 6$ to 8 feet, $40 \mathrm{c}$. each, $\$ 4.00$ per 12.

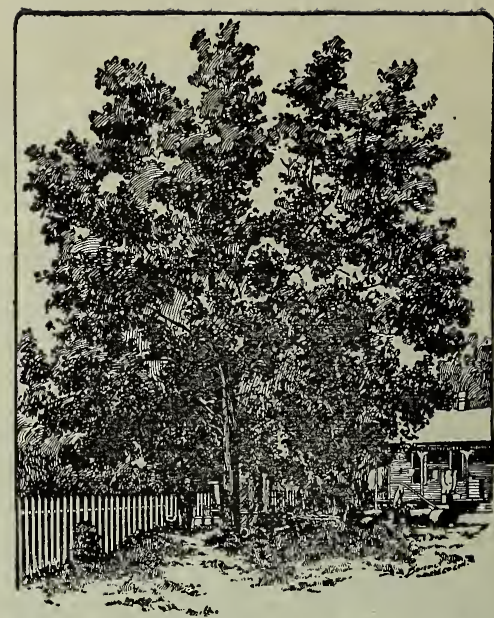

SUGAR OR ROCK MAPLE TREE.

Sugar or Rock Maple-This native tree of ours is a universal favorite for street planting, and desirable everywhere. It is considered a slow grower, but is long-lived. If planted in sod all trees or shrubs should be kept mulched for a year or two for best results. Price of Sugar or Rock Maple trees, 6 to 8 feet, $40 \mathrm{c}$. each, $\$ 4.00$ per 12 ; 8 to 10 feet, $50 \mathrm{c}$. each, $\$ 5.00$ per 12.

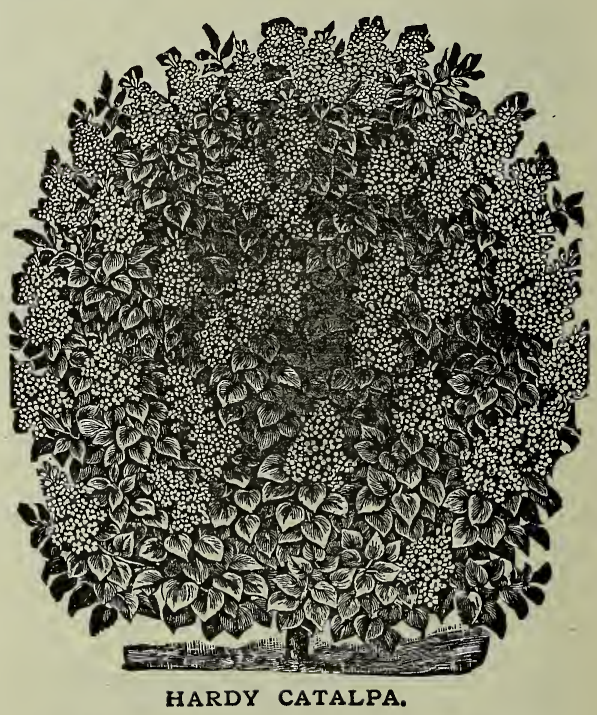

Hardy Catalpa-One of the most showy flowering trees. The flowers have a pleasant fragrance, and a tree in bloom attracts the sense of smell and sight. It makes a beautiful object on a lawn and should be in everyone's dooryard. Price of Hardy Catalpa trees: 8 to 10 feet, $50 \mathrm{c}$. each, $\$ 4.50$ per 12 ; 6 to 8 feet, $35 \mathrm{c}$. each, $\$ 3.50$ per 12 . 


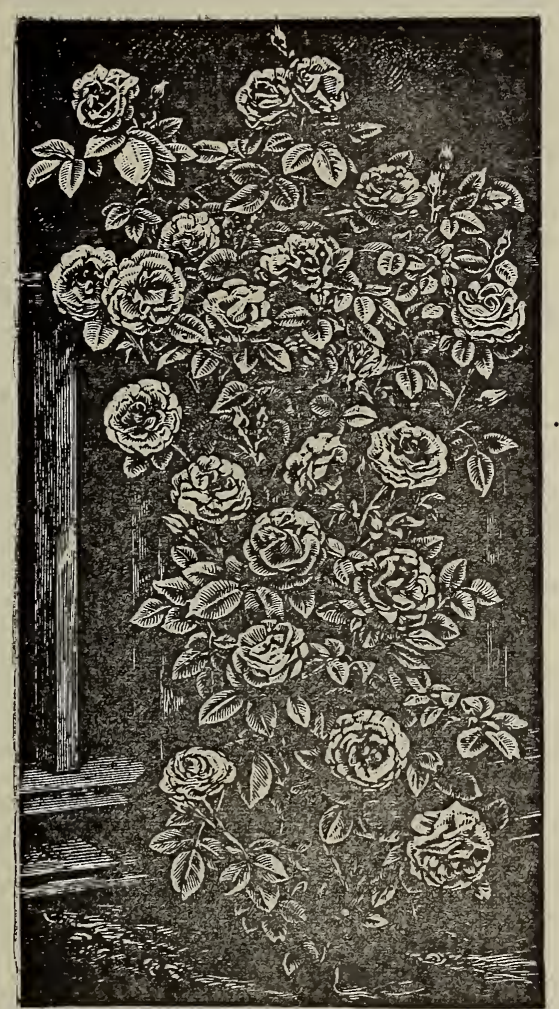

LIVE-FOREVER ROSE, GROWN AS A CLIMBER.

Mrs. John Laing-A beauty in clear, bright, shining pink; each bud in its long, serrated calyx with adjacent green foliage, forms a dainty and lovely boutonniere; immense, full blooms on long, stiff stems; sweetly scented. A good grower, constant bloomer, and hardy. Price 25c. each, \$2.50 per 12.

Magna Charta-A general favorite, prized on account of its strong, upright growth and bright, healthy foliage, as well as for its magnificent bloom. The color is beautiful pink, suffused with carmine. Price 25c., \$2.50 per 12.

\section{LIVE FOREVER ROSE}

A Bug-Proof, Hardy Rose-If you have tried growing roses and failed, try once more, for we have discovered a rose which lives long and is proof against insects and diseases. It is as easy to grow this variety as lilacs, corn or sunflowers.

I recommend this rose to all, especially to those who have not been able to succeed with roses. Plant it in large beds and you will have a display of bloom that will attract attention and admiration. Plant it in the form of a hedge-row and you will have something attractive and unique. You can train it low or high as you desire. Live-Forever Rose can be trained as a climbing or as a bedding rose, or it can be trained to a single stalk like a rose tree.

Price of Live-Forever Rose, strong, well-rooted 2. year bushes, 15c. each, 12 for $\$ 1.50$, 50 for $\$ 5.00$. 1-year bushes, or mailing size, suitable for hedges, 10c. each, $\$ 1.00$ per 12,50 for $\$ 4.00,100$ for $\$ 7.50$.

LaFrance-Silvery rose, with pink shades and satin-like petals of unsurpassed beauty; large, symmetrical and deliciously fragrant: blooms from June until frost; hardy with protection. A universal favorite. One of the most constant bloomers, flowering continually all the summer in the open ground. Price 25c. each, $\$ 2.50$ per 12.

Margaret Dick-on-White, with pale flesh center; petals very large, shell-shaped, fragrant, a fine variety; foliage very large, dark green. The finest white rose grown. Price 25c. each, $\$ 2.50$ per 12.

Anne de Diesbach-Carmine, a beautiful shade; very large. A superior garden sort; fragrant; one of the hardiest. Price 25c. each, $\$ 2.50$ per 12.

Baltimore Belle (Climber) - Pale blush, large, very double ; one of the best climbers. Price 25c. each, \$2.50 per 12.

Madame Plantier-Pure white, above me, dium size; full. Produced in great abund. ance early in the season. Foilage, rather small, seven leaflets. One of the best white roses for hedges and for massing in groups. Price of Madame Plantier, 25c. each, \$2.50 per 12.

Gen. Jacqueminot-Deep, brilliant shaded crimson, with large petals, globular with high center. Price $25 \mathrm{c}$. each, $\$ 2.50$ per 12.

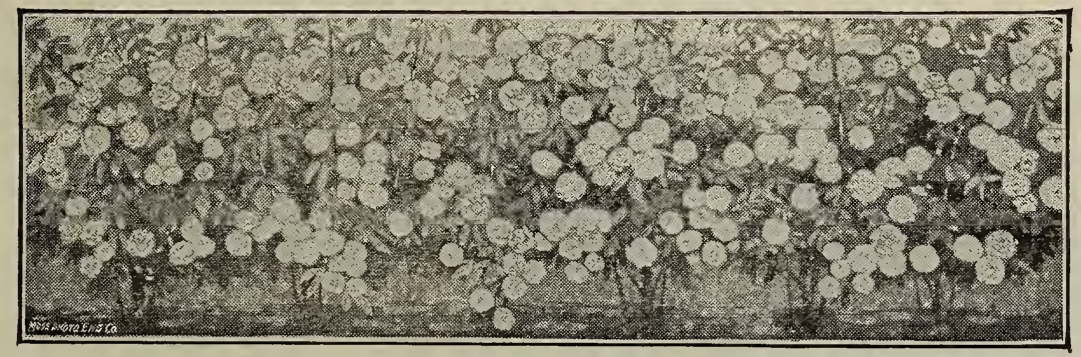

IIVE-FOREVER ROSE, GROWN AS A HEDGE. IT BLOOMS FIRST AND EVERY YEAR. 


\section{Price List of Items Not Given on Previous Pages}

CURRANTS-Red Cross Currant. New large and productive. Price, strong, one year old plants 50c. per $10, \$ 4.00$ per 100 , $\$ 35.00$ per 1,000 . New Diploma Gold Medal Currant, largest and best of all currants. Price for strong one year plants $8 \mathrm{c}$. each, 80 cents per 12 ; strong two year bushes 10c. each, $\$ 1.00$ per 12,50 bushes for $\$ 4.00$.

RASPBERRIES-Conrath Early Black Raspberry 35c. per $12, \$ 2.00$ per $100, \$ 18.00$ per 1,000. Ruby Red Raspberry. New and valuable, larger and better than Cuthbert. Price 50c. per 12, $\$ 2.50$ per 100 . Cuthbert Red. $50 \mathrm{c}$ per $12, \$ 1.25$ per $100, \$ 9.00$ per 1,000. Columbian Purple 50c. per 12, $\$ 1.75$ per $100, \$ 15.00$ per 1,000 . Kansas Black, 35c. per $12, \$ 1.50$ per $100, \$ 14.00$ per 1,000 . Loudon Red 50c. per 12, \$2.50 per 100 .

NUT TREES-Hazel (Filbert) 25c. each. Pecans, hardy seedlings 3 to $4 \mathrm{ft}$. 35c. each. Black Walnut, 5 to 6 feet 50c. each, 4 to 5 feet 35c. each. Butternut, 6 to 7 feet 50 cents each, $\$ 5.00$ per $12 ; 5$ to 6 feet, 35c. each, $\$ 3.50$ per 12 .

STRAWBERRY PLANTS-Corsican big strawberry. Senator Dunlap, early strawberry. Brandywine, late strawberry. Glen Mary and Cardinal (new). Price for all the above strawberry plants $25 \mathrm{c}$. per 12 , 75c. per $100, \$ 6.00$ per 1,000 . The above are all perfect blossom, except Cardinal.

ORNAMENTAL SHADE TREES-Carolina Poplar, best of al1 poplars, also Lombardy Poplar. Price 6 to 8 feet 20c. each. Norway Maple 8 to 10 feet $75 \mathrm{c}$. each, 6 to 8 feet 50c. each. Russian Mulberry 4 to 5 feet 25c each. American Elm 6 to 8 feet 35c., 8 to 10 feet 50c. each. Sugar or Rock Maple trees 6 to 8 feet $40 \mathrm{c}$. each, 8 to 10 feet 50c. each. Hardy Catalpa 8 to 10 feet 50c. each, 6 to 8 feet 35c. each. Cut Leaf Weeping Birch 75c. each. Wier's Cut-Leaved Maple 6 to 8 feet 50c. each. Purple Leaved Plum (Pissardi) 30c. to 50c. each. Horse Chestnut 4 to 6 feet, 50c. each. White Birch 6 to 8 feet 50c. Golden Willow 5 to 6 feet 35c. each. Linden or Basswood 6 to 8 feet 50c. Purple Leaf Beech 3 to 4 feet $75 \mathrm{c}$. each.

GOOSEBERRIES-Downing 2 years, $\$ 1.00$ per $12, \$ 7.00$ per 100 . Industry 2 years, large, 20c. each, $\$ 2.00$ per 12 .

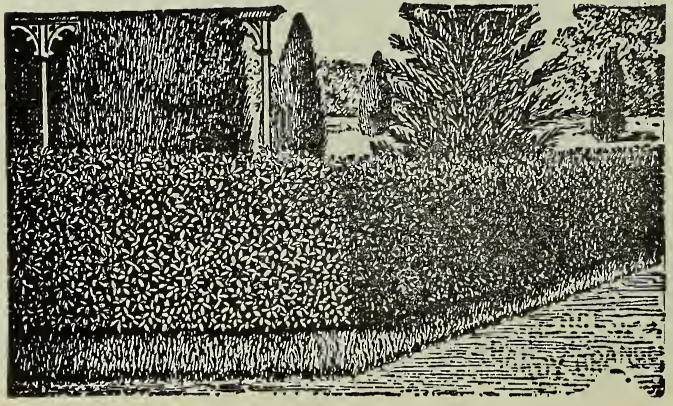

BLACKBERRIES-Snyder 50c. per 12, $\$ 1.50$ per $100, \$ 14.00$ per 1,000 . Eldorado 65c. per $12, \$ 3.00$ per $100, \$ 25.00$ per 1,000 .

DEWBERRIES-Lucretia 50c. per 12, $\$ 1.50$ per $100, \$ 10.00$ per 1,000 .

GARDEN ROOTS-Asparagus Conover's Colossal 2 years, 60c. per $100, \$ 4.00$ per 1,000. Giant Argenteuil, 1 year, 75c. per $100, \$ 5.00$ per 1,000 . Palmetto, 2 years, 60 c per $100, \$ 4.00$ per 1,000 . Rhubarb Linnaeus, 2 years, $\$ 1.00$ per $12, \$ 5.00$ per $100, \$ 40.00$ per 1000 .

ORNAMENTAL SHRUBS-Hardy Lilac 25c. to 50c. each. Notice that all following shrubs are 25c. each. Spiraeas, Mock Orange, White Fringe, Purple Leaved Barberry, Golden Bell, Snow Ball, Weigelas, Deutzia, Hardy Hydrangea, Golden Leaved EIder, Tree Cranberry, Althea. All the above shrubs we have in all the best colors at 25c. each.

ROSE BUSHES-Green's Hardy Liveforever rose bushes one year old 10c. each, $\$ 1.00$ per 12,50 for $\$ 4.00$, two years old $15 c$. each, $\$ 1.50$ per 12,50 for $\$ 5.00$. Other hardy rose bushes 2 years old 25c. each, $\$ 2.50$ per 12 .

FLOWERING PERENNIAL PLANTSThey blossom for almost a life time. The tops die down in winter but spring up new each spring. Perennial Phlox 15c. each, $\$ 1.50$ per 12. Yucca, with leaves like century plants, and tall white lily like flowering shoots, 25c. each. Paeonies in colors, strong roots $25 \mathrm{c}$. each, $\$ 2.50$ per 12 . Golden Glow, best of all yellow flowers 5 c. each, 50c. per 12.

EVERGREEN TREES-Norway Spruce 2 to 3 feet 25c. each. Scotch Pine 4 to 5 feet 25 c each. White Cedar 2 to 3 feet, 25c. each.

ORNAMENTAL GRA SS ES-Ostrich Plume best of all. 10c. each, 75c. per 12 . Old fashioned striped Grass 5c. each.

IMPLEMENTS FOR FRUIT GROWERS -If you desire spray machines, spray materials, apple parers, meat choppers, bone cutters, tree pruners, saws and other similar devices, send for Green's catalog of Fruit Growers Supplies which includes berry boxes, peach baskets, crates, etc.

HEDGE PLANTS AND TREESCalifornia Privet the most popular of all hedges. Two years branched $\$ 3.00$ per 100. Larger bushes $\$ 4.00$ per 100. Norway Spruce hedge 18 to 24 inches 15c. each, $\$ 12.00$ per hundred, 2 to 3 feet 25 c. each, $\$ 20.00$ per 100 . Arbor Vitae (or Cedar hedge) 12 to 18 inches $\$ 12.00$ per 100.

HARDY CLIMBING VINESJackmanni Clematis, Henryii Clematis, Ampelopsis Veitchii (Boston Ivy) 35c. each, $\$ 3.50$ per 12. Trumpet Vine, Hall's Japan Honeysuckle 20c. each, $\$ 2.00$ per 12 . Clematis Paniculata (white) 30c. each. 


\section{TREES AND PLANTS BY MAIL}

\section{Postpaid at Prices Attached.}

WE MAKE A SPECIALTY OF MAILING, all varieties of small fruit plants as listed in this Catalogue, and also some trees and shrubbery.

It is especially to meet the needs of those who live in distant states that our mail order department has been planned and perfected. We have so satisfactorily served our thousands of patrons during the past twenty years, that this line of patronage is rapidly increasing.

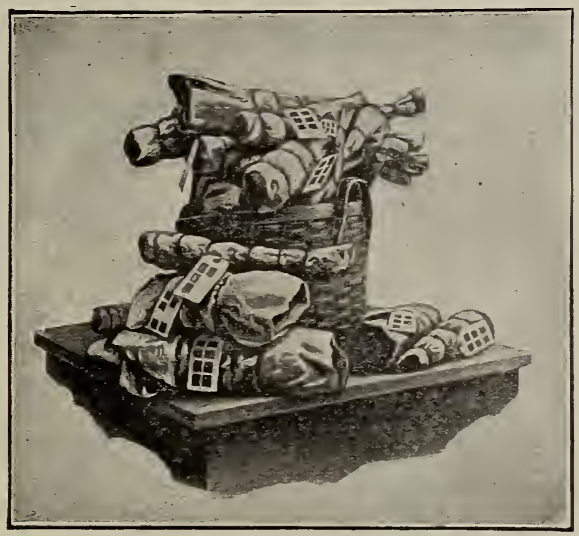

Orders packed ready for mailing prepaid at prices named on these pages.

Apple Trees-American Blush, Banana, Bismarck, Green's Baldwin Gano, Ben Davis, Grimes Golden, Jonathan, Rome Beauty, Winesap. Price 15 cents each, $\$ 1.50$ per 12.

Peach Trees-Elberta, Greensboro, Early Crawford, Late Crawford, Champion, Salway. Price 15 cents each, \$1.50 per 12.

Cherry Trees-Early Richmond, Montmorency, English Morello, IVindsor, Green's Tartarian, Napoleon, Gov. Wood. Price 20 cents each, \$2.00 per 12.

Quince Trees-Orange, Meech's, Champion. Price 20 cents each, $\$ 2.00$ per 12.

Pear Trees-(Std) Bartlett, Kieffer, Clapp's Fav., Seckel, Flemish Beauty, Anjou, Duchess. Price 20 cents each, \$2.00 per 12.

Pear Trees-(Dwf.) Duchess. 20 cents each, $\$ 2.00$ per I2.

Black Walnut, Catalpa, Silver Maple, Norway Spruce, (Evergreen). Price 10 cents each, $\$ 1.10$ per 12.

Grapes-as offered on pages 27 and 28 . Strong vines at same prices each and per I2.

Currants-Diploma, 10 cents. Red Cross, President Wilder, Fays. 5 cents each, 60 cents per 12.

Gooseberries-Downing. Price 10 cents each. Industry, 15 cents each.

Raspberries-(Red). Cuthbert, 50 cents per 12. Loudon, Ruby, 60 cents per 12. Syracuse new, $\$ 1.00$ each. (Black). Kansas, 40 cents per 12. (Purple) Columbian, 50 cents per 12.

Blackberries-Eidorado and Snyder. 60 cents per 12.

Strawberries-Corsican, Brandywine, Senator Dunlap, Pineapple Flavored, Cardinal. 25 cents per 12, $\$ 1.30$ per 100.
Asparagus-20 cents per 12, 75 cents per 100 . Rhubarb-- 10 cents each.

Sage -10 cents each.

Roses-Coq. de Alps, Paul Neyron, Gen. Jack, Dorothy Perkins, Crimson Rambler, Magna Charta, Lady Gay. Price 20 cents each. Live-Forever 10 cents each, $\$ 1.00$ per 12. Clematis-Purple and White, 25 cents each. Gladiolus-Mixed colors, 15 cents per six, 25 cents per 12.

Phlox-(Perennia1) in colors, 10 cents each, 75 cents per 12.

Peonies- (in colors), 25 cents each.

Golden Glow-5 cents each, 35 cents per 10.

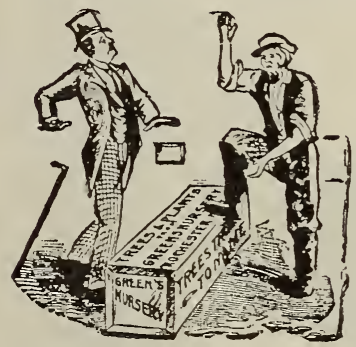

No Sir: Says old patron. No tree agent can sell me trees so long as $I$ can buy better trees true to name direct of $C$. A. Green and save half of my money.

\section{This is the way I Ordsr Plants, Trees and Vines.}

I send to Green's Nursery Co., Rochester, N. Y., for their illustrated catalogue which describes the various varieties of fruit and ornamental trees, vines and plants, and gives prices after the description of each variety. In that catalogue I find an order sheet on which I make out a list of the trees, plants, etc., which I desire to plant, attaching prices to it. Then I procure a postal money order, express mcney order, bank draft, or I enclose money in the letter, and register it and forward the order, money and my letter in an addressed envelope which I find in Green's catalogue. This is an easy way and a desirable way to order trees, plants and vines. This is the kind of business that Green's Nursery Co. has done during the past twentyfive years. Many hundreds of thousands of dollars have in this way been sent to Green's Nursery Co. and the orders have been faithfully filled, as is seen by the fact that such orders are constantly increasing. Every new year brings more orders than the past. Green's Nursery Co. is incorporated under the laws of New York State, with a paid-up capital of $\$ 100,000$. Any Bank can tell you in a moment about our responsibility and financial standing, by consulting Dun's or Bradstreet's Commercial Reports. 


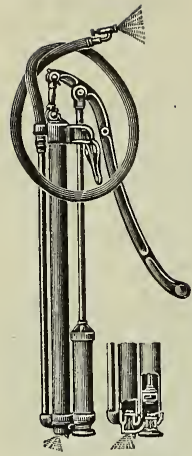
hose and nozzle ready to use, weight 30 lbs.

8-ft. Extension Pipe for higher trees.

pump is of a construction that is the best in all its parts. It is ready for operation when bolted to the staves of a barrel. The construction is such that the entire pump sets inside the barrel containing the liquid. It has brass ball valves and brass seats. Its plunger is brass fitted with hemp packing. The cylinder and discharge pipe are all of brass. Any kind of solution can be used in this pump. It will stand all kinds. The air chamber is 30 inches in length, enabling the pump to throw a uniform, constant and elastic spray. It is very powerful and easily operated. The Mechanical Agitator stirs the solution at the bottom, making it impossible for this pump to clog under any circumstances. There is nothing to get out of order.

Price No. 5, complete with Mechanical Agitator, 5 feet of three-ply dis. $\$ 7.98$
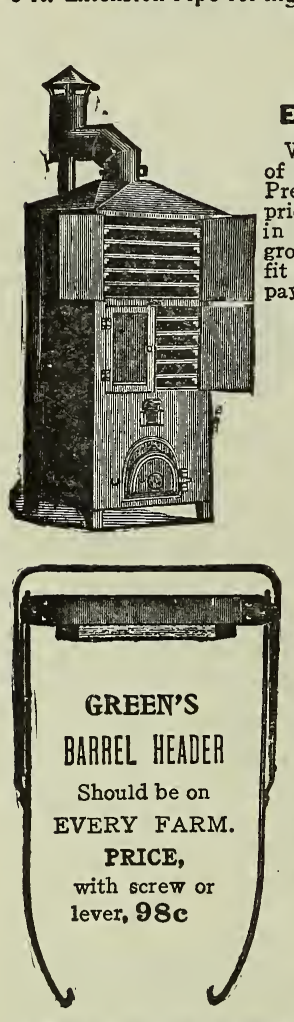

\section{FRUIT} EVAPORATORS.

We have a complete line of Fruit Dryers, Bleachers, Presses, etc. Write for prices on whatever you need in this line. Every fruit grower should have an outfit for evaporating fruit. It pays well.

\section{SENSIBLE WINE AND CIDER PRESS.}

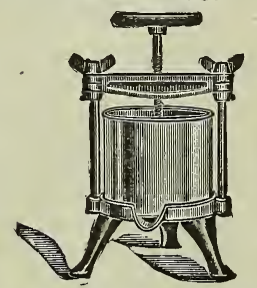

A well-made and handsome Press for making cider, wines, jellies, lard, syrups, etc. Made with. special reference to strength, and guaranteed against breakage under against breakage under and steel, stronger and better than the old wooden press. It has double en pre surbs.

\section{PRICE :}

Four quart curbs, weight 30 lbs. - $\$ 2.95$

Ten quart curbs, weight 40 lbs.

3.95

Large Clder Mills and Presses for home or commercial use at very low prices. Send for special descriptive circulars.

\section{GREEN'S HOME EVAPORATOR.}

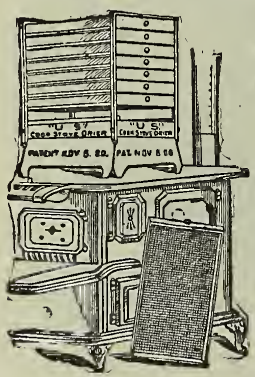

Thoroughly tested and ap. proved. Latest, cheapest. best. Can be used on anz stove, lries any fruit.

\section{Prico \$6.00} Special Price, \$4.75

READ THIS: To introduce our Home Evaporator and our No. 1 Parer, Corer, and Slicer (see description at top of page), we offer both for only $\$ 5.50$. Weightless than thirty pounds; can go by express or freight at very small cost. Just think of it! $\mathbf{A}$ Parer, Corer and Slicer with a Fruit Evaporator, all for only $\$ 5.50$.

\section{YOU CAINOT AFFORD TO LOSE THIS OFFER.}

Dear Sir-I found the Cook Stove Drier which $I$ bought of you last fall just as represented and I think the world of it; it readily paid for itself last fall. I dried 400 pounds of dried apples with it and it did its work perfectly.

Yours respectfully,

CHARLES B. REES.
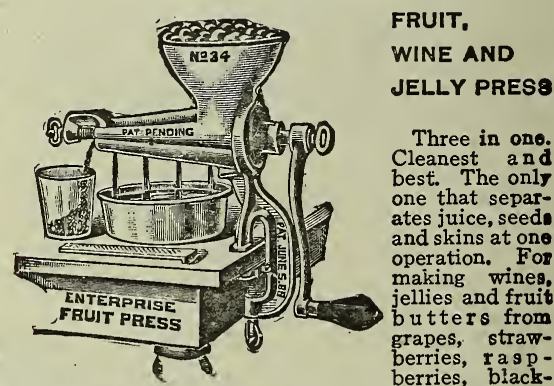

Three in ono. Cleanest and best. The only one that separates juice, seed. and skins at one operation. For making wines jellies and fruit butters from grapes, strawberries, ra $\mathrm{s}$ berries, black-

berries, gooseberries, currants, quinces, pineapples, etc. The dryness of the pulp may be regulated br thumb screw at the outlet. Weight only $15 \mathrm{lbs}$.

Special Price, complote, \$2.98.

The Best Spray Pumps made are sold by Green's Nursery Co. Send for our complete implement catalog containing everything for planting, spraying and marketing fruit. 


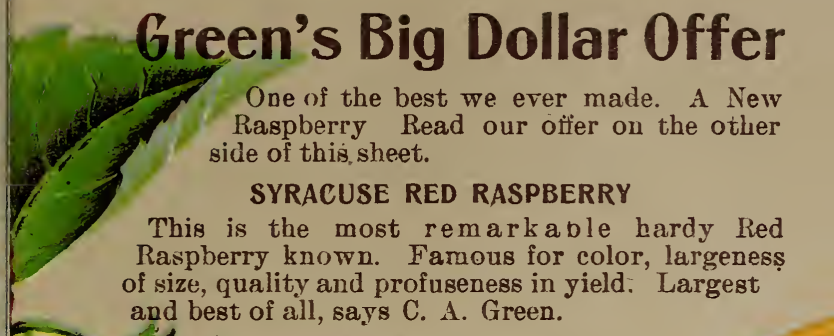

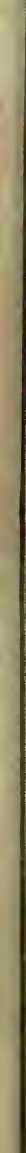

(See other side) 


\section{GREEN'S RASPBERRY NEW--SYRACUSE}

\section{A NEW HARDY VARIETY, LARGEST OF ALL}

THIS is one of the most remarkable Red 1 Raspberries ever known. These plants have been selling at $\$ 1.00$ a plant, but we have left a limited number and will make the following offer: Plants will be sent by mail in time for spring planting.

One New Syracuse Raspberry, One Liveforever Rose Bush, One New Diploma Currant, One year's subscription to Green's Fruit Grower, all for $\$ \mathbf{1 0 0}$.

The Liveforever Rose : - Blooms first year and every year.

The Liveforever Rose is so rapid in growth, and of such healthy foliage, that it is proof against all enemies. This is an old rose newly discovered, described by Pliny the historian, who lived when Pompeii was destroyed by the volcano Vesuvius. It was the national rose of the Roman Empire, known as the Hundred Leaf Rose. No rose on earth produces large double flowers more profusely than the Liveforever." When it first blossoms it is a deep pink. At the end of two weeks the roses have turned white. This variety is remarkably fragrant. A bed of them will scent a whole yard.

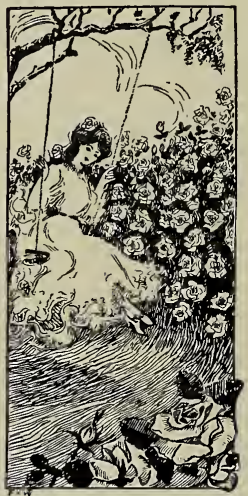

Liveforever Rose grown as a Hedge. 


\section{GREEN'S BIG PEACH OFFER}

FIVE PEACH TREES AND GREEN'S FRUIT GROWER TWO YEARS FOR $\$ 1.00$

TWO Elbertas, One Late Crawford, One 1 Early Crawford and One Salway. Trees delivered at your home, with all charges paid, in time for spring planting. These five peach trees and Green's Fruit Grower every month for two years, all for $\$ 1.00$.

Green's Fruit Grower, Rochester, N. Y.

\section{A Remarkable Dollar Offer:}

Two Elberta Peach Trees, two Diploma Currant Bushes and two Liveforever Rose Bushes all delivered free to your home in time for spring planting, and Green's Fruit Grower two years, or until January 1911, all for $\$ 1.00$.

Green's Fruit Grower,

Rochester, N. Y. 
min

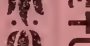

.

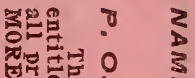

iii $x$

1. 2

.

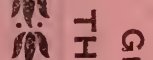

खण्

DE \& क

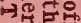

ก०

Bम

$\rightarrow$ 递

可要

要

बदेध

चक्ष

핑

तिक्षित्र

버ㅇㅝㅠ.

पत्र

12 I $\Leftrightarrow$

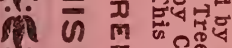

.. $m$ क

(1) 2 承

In 0 i

ii $c$ ज $\gg Q$

- $\mathrm{z}$ 己

索 $\mathrm{O}$ 员

$》$ 舟

级

- ᄀ<

I

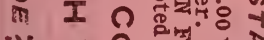

iti $\lesssim 0$

0 : m $^{-1}$

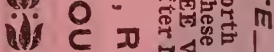

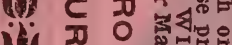

(4) $D$ D

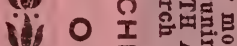

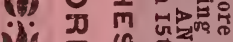

(ii) 0 o 0 政电。

iij $m$ 开

기 ग

il :

ili $\geq$ 워

ii) $<$ क्षे

idi $<$ :

iiis

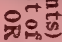

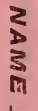

(n)

n

i

i

si

a

A.

4

A

6

6

tas

sine

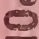

인

4

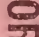

-nd

?

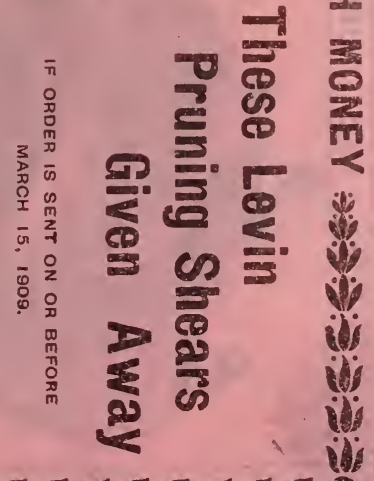

ij:

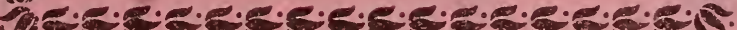
G. 


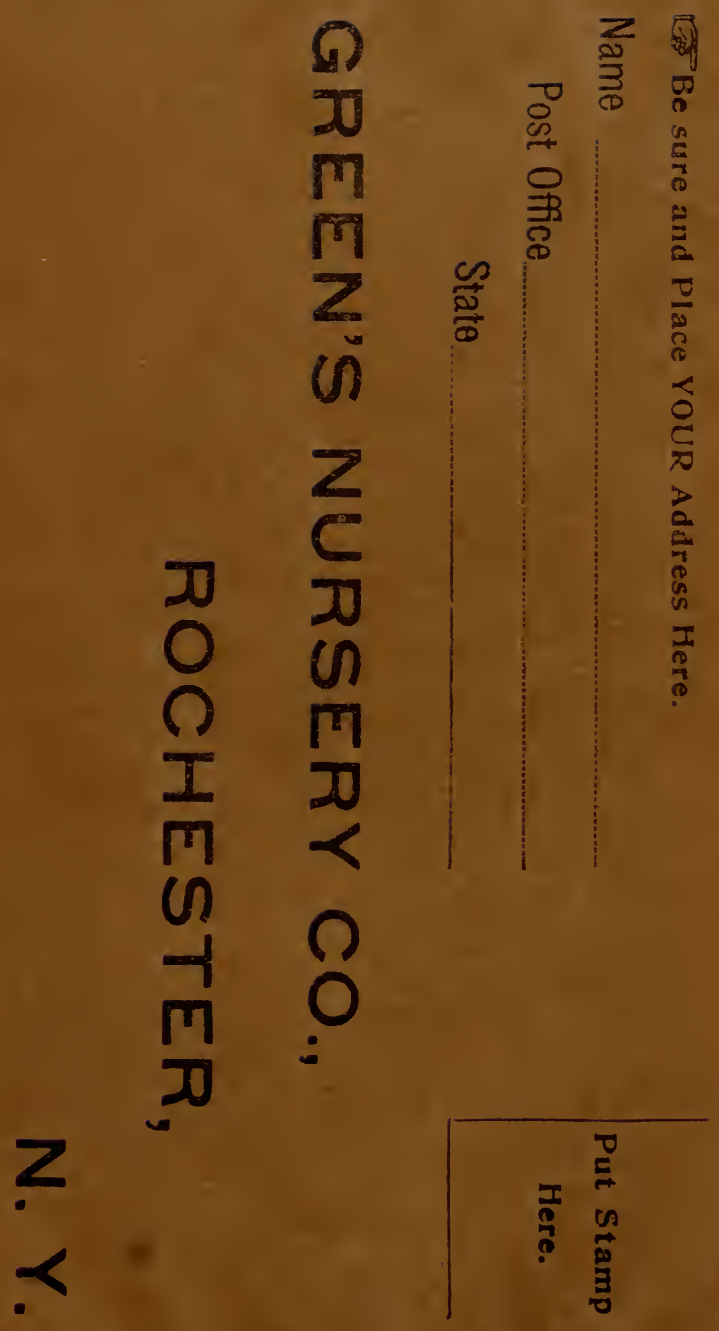



HOW TO 0 i 10 . We employ no agents. This Cataiogue is our only salesman. Fill out this Order Draft on New York, and mail all to us in enclosed envelope. By this method you save half the money you would have to pay agents for trees. We have filled orders in this way for twenty years, and are well known all through the country. You can learn of our responsibility through any commercial agency, bank or banker, or of the postmaster at Bochester, N. Y. Wo pack and ship all Winter to Southorn States from troes stored in our large collare Our Rogular Spring Shipping Soason opens from April first. State positivoly how we are to ship, whether by Freight,
lispress, or Mail. If by Ireight or Express, give name of $\mathrm{B}$. B. station and your post-office.

\section{GREEN'S NURSERY COMPANY, Rochester, N. Y.}

Name,

Post Office,

County,

State,
P. 0:0rder, \$

Draft,

Cash,

Total, $\$$

Be sure to give the name of Express Office if desired by Express; or Freight Station if desired by Freight. Also name your Post Office Address, too.

Express Office,

Express Co.,
Freight Station,

Railroad,

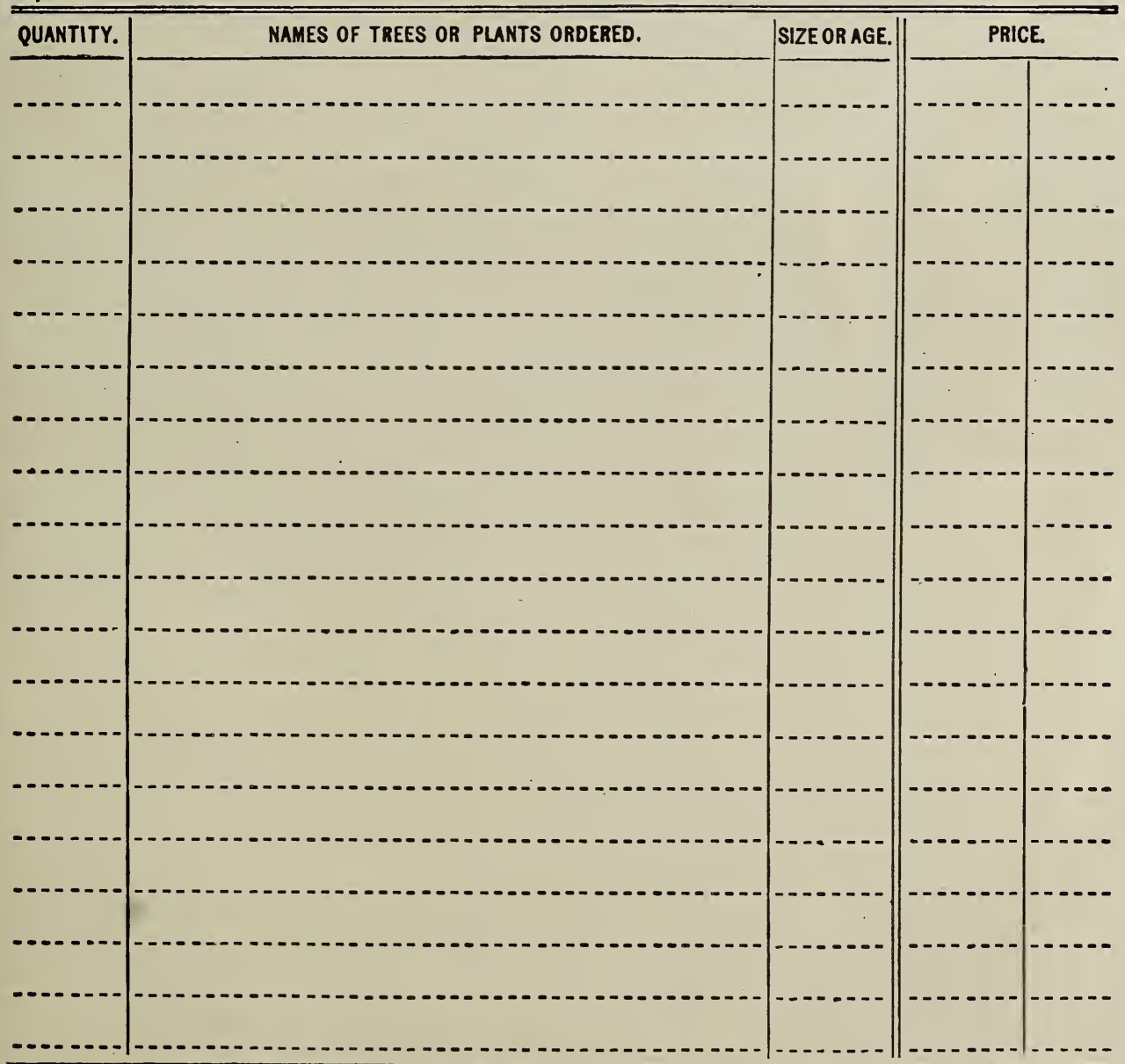

See Other Side for Mail Order Sheet.

OUR GUARANTEE. While we exercise the greatest care to have our stock genuine and reliable, we agree to replace, on proper proof, all that may prove untrue to name as labeled, and it is hereby mutually agreed that our replacing it or offer to replace it shall operate as a liquidation of all damages. 


\section{MAIL ORDER SHEET.}

OREEN'S NURSERY CO., Rochester, N. Y.-Please send by mail to addres given as belon.

Name,

Post Office,

County,

State,
P. 0. Order, \$ Stamps, - -

Cash,

Total, $\$$

See Other Side for Express or Freight Order Sheet.
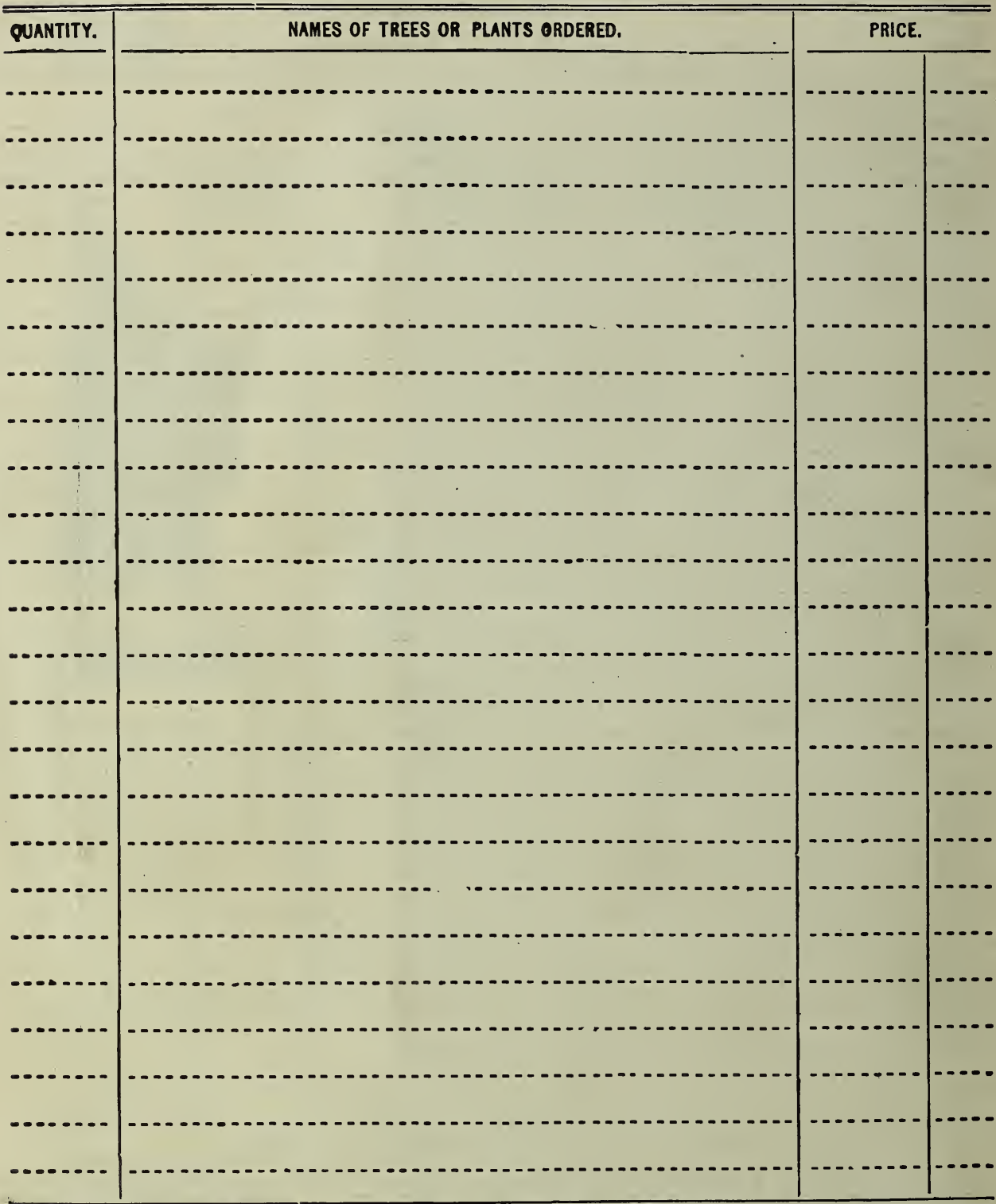

DON'T MIST 1 KE. This is the order sheet to use when you desire plants, etc., by Mail. (Soe int pase for list.) If you desiro plants and treas by Axpress or Freight, seo other side.

Praba's NURsaRY CO., Recherter, A. Y. 